Florida International University FIU Digital Commons

7-14-1995

\title{
Natural disaster and household recovery in the aftermath of hurricane Andrew : a case study of four Hispanic households in South Miami Heights
}

Manuel Rafael Alba

Florida International University

DOI: $10.25148 /$ etd.FI13101561

Follow this and additional works at: https://digitalcommons.fiu.edu/etd

Part of the Sociology Commons

\section{Recommended Citation}

Alba, Manuel Rafael, "Natural disaster and household recovery in the aftermath of hurricane Andrew : a case study of four Hispanic households in South Miami Heights" (1995). FIU Electronic Theses and Dissertations. 1187.

https://digitalcommons.fiu.edu/etd/1187 
FLORIDA INTERNATIONAL UNIVERSITY

$$
\text { Miami, Florida }
$$

\title{
NATURAL DISASTER AND HOUSEHOLD RECOVERY IN THE AFTERMATH OF HURRICANE ANDREW: A CASE STUDY OF FOUR HISPANIC HOUSEHOLDS IN SOUTH MIAMI HEIGHTS
}

\begin{abstract}
A thesis submitted in partial satisfaction of the requirements for the degree of MASTER OF ARTS
\end{abstract}

IN

COMPARATIVE SOCIOLOGY

by

Manuel Rafael Alba 


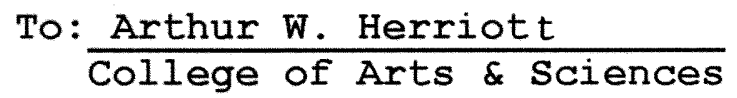

This thesis, written by Manuel Rafael Alba, and entitled Natural Disaster and Household Recovery in the Aftermath of Hurricane Andrew: A Case Study of Four Hispanic Households in South Miami Heights, having been approved in respect to style and intellectual content, is referred to you for judgement.

We have read this thesis and recommend that it be approved.

$$
\text { Wáltér frilis Peacock }
$$

Hugh Gladwin

Jathes P. Ito-Adler, Major Professor

Date of Defense: July 14, 1995

The thesis of Manuel Rafael Alba is approved.

Dean Árthúr W. Herriott

College of Arts and Sciences

Dr. Richard L. Campbell

Dean of Graduate Studies

Florida International University, 1995 
${ }^{\circ}$ COPYRIGHT 1995 by Manuel R. Alba

All rights reserved

iii 
ABSTRACT OF THE THESIS

NATURAL DISASTER AND HOUSEHOLD RECOVERY IN THE AFTERMATH OF HURRICANE ANDREW: A CASE STUDY OF FOUR HISPANIC HOUSEHOLDS IN SOUTH MIAMI HEIGHTS

\section{by}

Manuel Rafael Alba

Florida International University, 1995

Miami, Florida

Professor James P. Ito-Adler, Major Professor

This thesis explores the aid received by four Hispanic households towards recovery after Hurricane Andrew. The four households resided in South Miami Heights, a suburb of Miami. Through the use of questionnaires, information was gathered on various storm related topics. Because the Cuban community in Miami is influential, the role of the Cuban enclave is studied in relation to the recovery of these households. The influence of an urban environment on the extended family ties of these households is also addressed since the literature argues that these ties are powerful among Hispanics. Results show, that aid primarily came from two sources. Furthermore, the Cuban enclave appears to have had no discernible role in the recovery of these households. Finally, an urban setting did not appear to diminish extended family ties. 


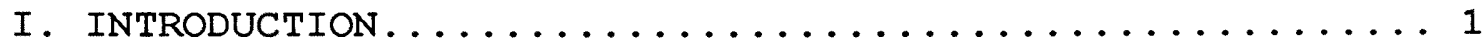

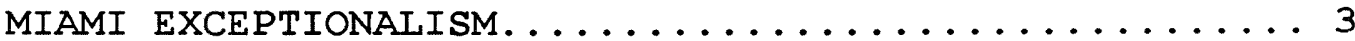

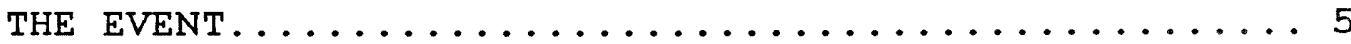

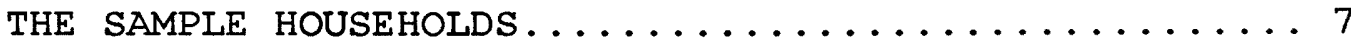

II. THE RESEARCH ISSUES..................... 10

HOUSEHOLD RECOVERY, URBAN KINSHIP, AND THE CUBAN

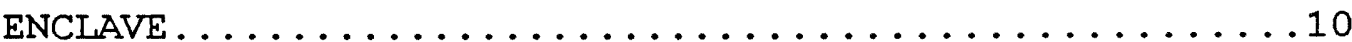

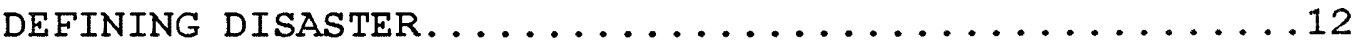

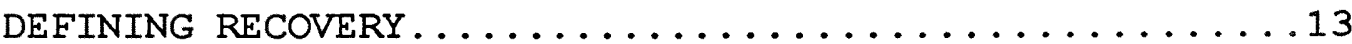

DIFEERENT PATHS TOWARDS ACHIEVING RECOVERY.......17

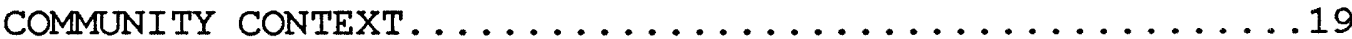

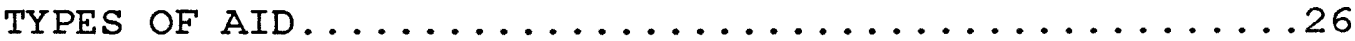

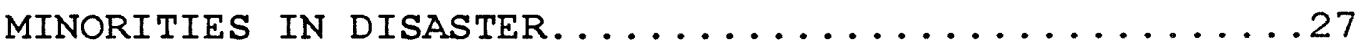

III. THE STUDY ............................ 29

THE CASE STUDY: ANTHONY F.C. WALLACE'S THEORY......29

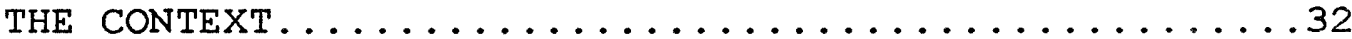

INHABI TANTS . . . . . . . . . . . . . . . . . 34

STEADY STATE: SOUTH MIAMI HEIGHTS BEFORE ANDREW.....36

POST HURRICANE ANDREW.................48

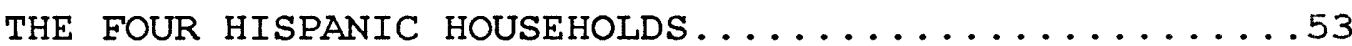

DATA COLLECTION TECHNIQUES...............65

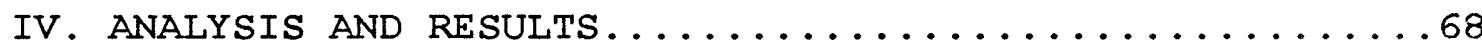

TYPES OF AID RECEIVED..................68

HOUSEHOLD RECOVERY ....................

THE ROLE OF URBAN KINSHIP AND THE CUBAN ENCLAVE....74

V. CONCLUSION........................ 76

RESEARCH QUESTIONS AND SUMMARY ............76

IMPLICATIONS OF THE STUDY AND RECOMMENDATIONS......86

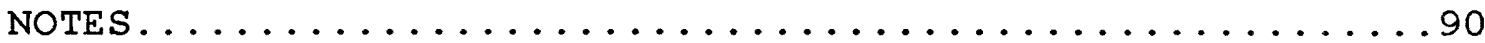

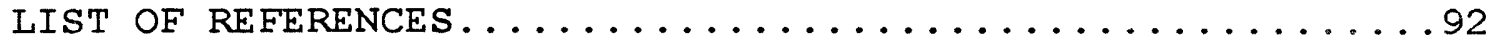

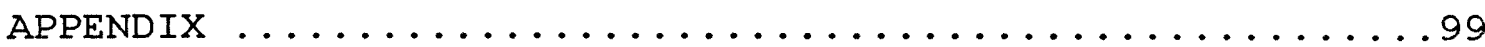




\section{INTRODUCTION}

This thesis is a case study of household recovery following a massive natural disaster; specifically, recovery from the impact of Hurricane Andrew on families living in South Miami Heights, a suburb of the city of Miami in South Florida. This hurricane, which struck on August 24, 1992, was one of the most costly and devastating natural disasters to strike the continental United States. South Florida, which had not experienced a direct strike by a hurricane in over a quarter century, was devastated by Hurricane Andrew. Thousands of homes and businesses were destroyed and several hundred thousand people were left homeless. The extreme suffering and massive destruction caused by Andrew prompted the local, state, and federal governments to reevaluate both their preparedness for disasters and their handling of disaster situations. Furthermore, Dade County, where the city of Miami is located, eventually moved to upgrade the building codes for residential and commercial structures since the old ones proved ineffective in the face of this cataclysmic event.

In the present instance, recovery from such a disaster took place at many levels: societal, community/neighborhood, family/household, and individual. However, recovery at the household level (i.e., household meaning a residential unit and not a kinship unit as would be implied by the term 
extended family) was the main focus of this study. Household recovery was explored through intensive interviews with four Hispanic households that were resident in South Miami Heights at the time of Andrew's impact. The sample of four Hispanic households consisted of families with the following national origins: Cuba, Mexico, Nicaragua, and El Salvador. Members of these households were interviewed in-depth about how they coped in the aftermath of this storm and the assistance they received towards recovery from relatives, co-ethnics, government agencies, and non-governmental organizations (NGOS) .

Hispanic households were the focus of this study because of the important role that ethnicity plays in Miami. Like most American cities, Miami has various ethnic and racial groups that are an integral part of life in the area. In addition to Hispanics, Miami's population includes large numbers of African-Americans, Haitians and Haitian-Americans, and Jewish-Americans, for example. Due to the powerful Cuban presence in the area, which has been characterized by Portes (1980) and others (Cobas 1987; Forment 1989; Pérez 1986) as a Cuban "enclave," and the salient presence of other Hispanic groups, a study of household recovery among Hispanics, including Cubans and non-Cubans, was chosen.

This study was part of a larger project conducted by the Florida International University Disaster Research Team in 
South Miami Heights beginning in May of 1993, less than a year after the storm. It complements other work (Beer 1994; Dash 1995) on this disaster by providing a case study of Hispanic household recovery. The disaster research team, which was comprised of faculty members, graduate students, and hired interviewers, conducted 209 completed interviews on various storm-related topics as part of the South Miami Heights Survey (1993). While household recovery was briefly explored in the initial South Miami Heights Study, the current study (South Miami Heights Household Recovery Survey) focused specifically on this topic among a Hispanic household sample.

\section{Miami Exceptionalism}

Miami, in terms of its racial and ethnic makeup, is obviously different from other cities in the United states. of course, every city is unique in its own way; but the issue here is in what ways are these differences relevant for the present project? One salient difference is that in Miami, an ethnic minority, Hispanics, outnumbers the majority, or nonHispanic whites, i.e., Anglos and Jews (Grenier and Stepick 1992:5). If one goes by numbers alone, Latins are not a minority in Miami at all. Furthermore, if one takes into account political and economic power, various Hispanic groups have left their marks throughout the city, particularly Cubans. This is most strongly argued in works using the 
notion of a Cuban enclave (Pérez 1992; Portes 1980 and 1987).

Portes and Bach (1985:203), argue that an ethnic enclave is "a distinctive economic formation, characterized by the spatial concentration of immigrants who organize a variety of enterprises to serve their own ethnic market and the general population." Several researchers (Portes and Bach 1985; Pedraza-Bailey 1985; Portes and Manning 1986; Forment 1989; Portes and Stepick 1993) have discussed the important role that the enclave plays for Cubans residing in Miami. Grenier and Stepick (1992), for example, credit the enclave with helping Cubans to establish a solid economic base in Miami. Another researcher (Pérez 1992:93) likewise acknowledges that the enclave has helped Cubans in the area in numerous ways. Of special note, he argues, is that in order for Cubans to conduct business in the enclave they do not need to speak English since virtually anything can be resolved in Spanish. Another advantage provided by the enclave is the relative ease with which Cubans find employment. A large number of Cubans find work in businesses owned by fellow Cubans. Working for a fellow Cuban often leads to the establishment of ones own business with the aid of the former employer. It is not surprising then, that $20 \%$ of Cubans started their own business in the 1970s and 1980s (Portes 1987:351-352). Finally, Pérez (1992:90) argues that "the presence of such an enclave is one of the reasons Cubans are concentrating in South Florida." 
The enclave, it can be argued, provides Cubans with opportunities that are not available to them in other parts of the United States. For example, as mentioned above, in order for Cubans to conduct business in Miami it is not necessary for them to speak English (Pérez 1992:93). Of course, the opportunity to conduct business in Spanish extends beyond the Cuban population as other Hispanic groups are also afforded the opportunity to conduct business in their native tongue. Furthermore, Cubans are a political force in the area whose views are represented by elected officials both locally and state wide. The presence of the enclave, the extensive use of Spanish, and the political strength of Cubans therefore, offered an excellent opportunity to explore the recovery of Hispanic households in the area following a major natural disaster.

\section{The Event}

When Hurricane Andrew roared through South Florida in the early morning hours of Monday August 24, 1992 it was both a novel and terrifying experience for most of the people living in the storm's path. In spite of South Florida's reputation for hurricanes, Andrew was the first major hurricane to make a direct strike on the area in over a quarter century. The closest most people living in the southern tip of the Florida peninsula had come to experiencing a hurricane had occurred in 
1979 when Hurricane David brushed by the area. ${ }^{1}$

Unlike David, however, Andrew did not merely pass by offshore with nothing more than strong winds to note its passing. Andrew left in its wake a path of destruction which cut directly through a densely populated zone. In the few hours that it took to make its way through the area Andrew caused several deaths and billions of dollars in damages.

The sheer physical destruction caused by Andrew was immense. More than 130,000 homes were seriously damaged or destroyed, forcing more than 200,000 people to seek alternate shelter. Likewise, 8,000 businesses were also destroyed. Families which had lived in the area for years suddenly found themselves without a home. For many the impact was doubly devastating as not only homes but businesses and the employment provided by them were also lost (Peacock and Morrow n.d.:6) .

Thirty-one schools, 59 health facilities and hospitals, and Homestead Air Force Base were also damaged or destroyed (Ibid). Children, whose schools were heavily damaged or had been completely destroyed, had to be driven or bussed to schools in other locations. Where this was not feasible they had to attend classes in school trailers set up amidst the wreckage of what had once been vibrant school buildings. Many hospitals, which could have provided care for those hurt during the storm or afterwards, were nearly or completely shut 
down because of damage and, in several instances, they were completely destroyed.

While most of South Florida was affected to some extent by Andrew, the area that experienced the heaviest damage is located south of Miami's center (Figure 1). This area suffered the most damage because it either lay in Andrew's direct path or near it as the storm made its way across the peninsula. While other areas suffered relatively limited damage, zones in this area were virtually obliterated.

\section{The Sample Households}

The composition of the four Hispanic households that took part in this study varied in numerous ways. The Cuban household contained the fewest individuals, two, as well as the oldest ones, the male was 62 and the female 58 at the time of the South Miami Heights Household Recovery Survey. Both of these individuals were born in Cuba and immigrated to the United states as adults. The Nicaraguan household contained five members, three of which, the male, adult female, and eldest daughter, were foreign born. Specifically, the male was born in Nicaragua while his wife and oldest daughter were both born in Honduras. The two youngest daughters were born in the United States. At the time of the South Miami Heights Household Recovery Survey, the male was 50 years old, the adult female was 34, while their three daughters were 12, 
eight, and six years of age.

of the four households, the Mexican one was the largest with seven members, four of which were female. All of the individuals in this household were born in Mexico. When this household was interviewed for the South Miami Heights Household Recovery Survey, the oldest adult male was 50 years of age, the oldest adult female 45, their three daughters were 24, 23, and 18, while their sons were 21 and 10 years of age. Like the Nicaraguan household, the Salvadorian household also contained five members. Of the five members, the adult male, who was 35 at the time of the second survey, was the only one born outside the United States, specifically, in El Salvador. At the time of the second survey, the adult female was 29 years of age, one younger male was 10 and the other eight, while the youngest female was six years old. 


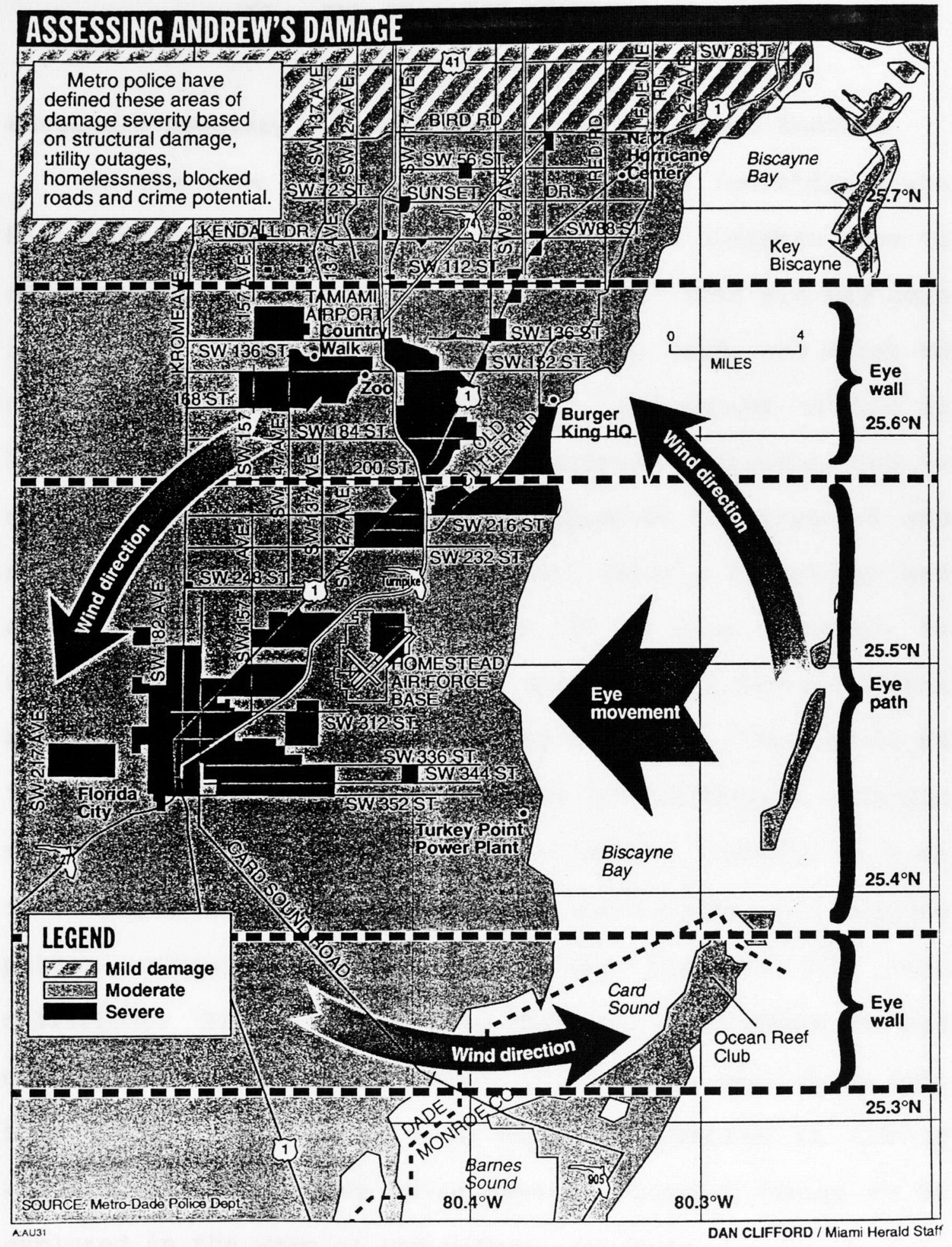

Figure 1

Dade County. 


\section{THE RESEARCH ISSUES}

\section{Household Recovery, Urban Kinship, and the Cuban Enclave}

In the wake of most natural disasters individuals who have not suffered the direct impact of the disaster tend to offer aid to kin that have been impacted. This aid may come in the form of temporary shelter, clothes, food, and water to name only a few things. Naturally, the amount of aid is limited depending on available resources, logistics, and so on. The disorganization and breakdown of the physical and social infrastructure can also limit ability to deliver aid even if the intention is present. It is also important to remember that not all individuals are able to offer aid to kin who have been victims of a natural disaster. This could be the case for several reasons, such as inadequate economic resources or the sheer physical distance. Finally, in some instances it may be unnecessary for kin to offer aid because public response to victims of the disaster has been sufficient. Still, it is likely that most individuals who are economically and physically able, for example, will offer some form of aid to their kin in such a situation if aid is required. These topics raise several relevant issues to be explored in the wake of any natural disaster.

It is worth examining the effect that living in an urban environment has on the role of kinship in disaster situations. 
This is particularly true in this thesis not only because South Miami Heights is urban, but also because of the interaction between ethnic identity and urban residence. In this instance, all the households studied are Hispanic. Moreover, all four of the households, whether Cuban or nonCuban, contain individual members who immigrated to the United States. In one case all but one family member was born in the United states. Yet, even in this instance, the individual born in this country was enculturated in a Hispanic environment where extended kinship (i.e., intimate familial relations extending beyond the nuclear family) is considered by several researchers to be significant (Graves and Graves 1974:133; Keefe 1979, 1980). Therefore, the question can be posed, what effect did living in an urban locale have on the non-residential kin relations of Hispanic households in the aftermath of Andrew and what did it mean for their recovery?

Finally, another issue taken up in this study is the presence of the Cuban enclave in Miami (Cobas 1987; Forment 1989; Model 1992; Pérez 1986; Portes 1980:335, 1987; Sanders and Nee 1987) and its impact on recovery. The Cuban enclave, defined above (pages 3-4), is the presence of a large Cuban population in Miami, which has been both socially and economically successful in the area and which strives to maintain its cultural and ethnic identity (Portes and Manning $1986: 58-61)$. 


\section{Defining Disaster}

A range of definitions have been proposed for the term "disaster." Defining a disaster as any destructive event in which lives are lost, property is destroyed, and recovery is attempted, to name just a few criteria, appears relatively straightforward. Nevertheless, a final consensus in the field of disaster research lies beyond our grasp according to Bates and Peacock (1989:349-50). They point out that the perspectives applied in the study of "disasters" vary according to the focus and interests of individual researchers and are rendered complex by the very "interdisciplinary nature of disaster research." They go on to argue that researchers offer differing definitions depending on whether they are studying the preparedness and warning phase, the emergency phase, or the recovery phase. Furthermore, they argue that differences exist even between researchers in the same field, not to mention between those in different fields, as a result of the particular component of a local system they view as being affected by the disaster. Bates and Peacock list these components as including the physical ecosystem and environment, the man-made infrastructure, the mental and physical well-being of those experiencing a disaster, and the social system $(1989: 350)$.

While it may appear that the inability to settle on a single definition might hinder the study of disasters, this is 
not necessarily the case. On the contrary, settling for a single definition would detract from disaster research since "the various theoretical perspectives are actually working on entirely different problems and each may be of practical importance in its own right" (Bates and Peacock 1989:351). In this vein, the working definition proposed by Bates and Peacock will be used (1989:352):

... [a disaster] occurs when an environmental event overwhelms a sociocultural system's capacity to adapt to its environment by the use of established, institutionalized, routine or "normalized" patterns of activity or behavior without being threatened with collapse into chaotic, randomized, individualized adaptive behavior.

This appears to be an apt characterization of what occurred in South Florida, including the area of South Miami Heights, as a result of Hurricane Andrew.

\section{Defining Recovery}

What does "recovery" mean in the context of "a household recovering from a disaster?" Is it the process of a household regaining all that it had prior to the disaster? In other words, the things it would have had, such as the same or equivalent home, transportation, or household possessions, had the disaster not occurred. On the other hand, should this be called "restoration" and the term "recovery" limited to the level of attainment the household would have probably reached at a future point in time, and which it eventually does 
achieve in the post-disaster period, if, again, there had been no disaster (Bates, Killian, and Peacock 1984:443)? This is a critical question that disaster researchers must deal with but that cannot be addressed in this research because it demands greater attention than can be given here. Therefore, in this thesis recovery is heuristically conceptualized as being achieved once a household is back to the level it had prior to the disaster. This applies to whether one is referring to the economic level or any other.

Anthony F.C. Wallace (1956a), in his study of the impact of the 1953 Worcester (Massachusetts) tornado, used the notion of "rehabilitation," his term for recovery, to conceptualize what victims of a disaster attempted to accomplish following such an event (p. 88). Rehabilitation, included restoring people, "insofar as possible (and desirable) to their preimpact physical and emotional status." Likewise, rehabilitation aimed at returning the physical environment i.e., buildings, automobiles, etc., to the way they had been prior to the disaster "(again as far as possible and desirable)." Obviously, the level of recovery wallace is describing is one based on a community scale. Nevertheless, it could equally well apply to individual households and persons as they attempt to attain these goals for themselves (Wallace 1962:15-16).

Bolin and Bolton (1983), define recovery specifically at 
the family level. They argue that a family will think that it has recovered at the point that its "general lifestyle and activity patterns" are similar to how they were before the disaster (p. 131). That is, once a family is able to do the things it did prior to the storm without worrying about economic factors, for example; assuming, of course, that they did not worry about these prior to the disaster; it will consider itself recovered.

In another study Bolin (1976), looks at recovery somewhat differently. According to Bolin (1976:268) while recovery does dictate that homes be reestablished, it also demands that the roles played by family members be changed in order to fit the "postdisaster social milieu." Thus, he argues, as do the others, that houses must be restored or a similar dwelling located. However, though Bolin notes that the psychological makeup of individuals must be adjusted, as does wallace, he appears to limit this to relations between family members. Wallace, applies this to all relations in his reference to "pre-impact emotional status" (1956a:88). Whatever the differences are in these two arguments they appear to be minor as the ultimate goals of recovery they present are very similar.

Finally, Bates and Peacock (1989:353), define recovery "as the process by which a system which has experienced a structural failure of this sort, reestablishes a routine, 
organized, institutionalized mode of adaptation to its postimpact environment." This requires that the population reorganize its social life without necessarily changing its social organization and behavior patterns to a large extent. Though assumed in the other definitions, this is the only one that specifically mentions a need to readjust to the new environment. Like the others though, recovery still entails a need to achieve a stable existence within the new environment.

Yet, a very critical point that the last two researchers make is that adapting to the new environment may lead to a "degenerative change." Simply stated, the adaptive response of the population could lead to greater loss in the event of another disaster as well as less successful adaption to the new environment than was attained in the previous one. Recovery can thus be something that is never achieved. As a result of this, Bates and Peacock argue that "... the term recovery is misleading and probably ought to be abandoned as a term used to refer to the final stage of the disaster process" (1989:353).

In the present thesis, I will use the term household recovery, because, while it may be possible that the households that took part in this project are more vulnerable in the face of another hurricane, they did appear to have successfully adapted to their new situation. Their behavior 
in the face of another disaster is thus a moot point.

\section{Different Paths Towards Achieving Recovery}

There are a number of different modes of recovery available to victims of a disaster. Surprisingly, there only appear to be a handful of researchers in the field who delineate different modes of recovery. These are in chronological order: Bolin (1976), Bolin and Trainer (1978), Bolin and Bolton (1983), and Bates and Peacock (1989).

Achieving recovery via different modes was first referred to by Bolin (1976:273). Later Bolin and Trainer (1978:236), expanded this theory based on a cross-national study of family recovery following two natural disasters. Through their work with victims of the 1972 Managua (Nicaragua) earthquake and the Rapid City (South Dakota) flood, these researchers identified three types of family recovery: (1) autonomous mode; (2) kinship mode; and (3) institutional mode. A few years later, Bolin and Bolton (1983:143) likewise presented a discussion of the varying modes which households might take towards recovery, which expanded the discussion but added little new to the original picture of modes of recovery.

Bates and Peacock returned to this topic in 1989, mainly as a result of their work with victims of the 1976 Guatemalan earthquake. These researchers classified two modes of recovery: (1) indigenous or independent recovery and 
exogenous or dependent recovery (1989:358). These were further broken down into sub-modes: (a) individualistic selfhelp mode, (b) collective or cooperative mode, and (c) bureaucratized paternalistic mode for (1) indigenous and independent recovery, and (a) independent beneficiary mode, (b) collaborative partnership, and (c) bureaucratized external paternalism for (2) exogenous or dependent recovery as shown in the following typology.

1. Indigenous or independent recovery
a. Individualistic self-help mode
b. Collective or cooperative mode
c. Bureaucratized paternalistic mode

2. Exogenous or dependent recovery
a. Independent beneficiary mode
b. Collaborative partnership
c. Bureaucratized external paternalism

Looking at these modes in some detail, Bolin and Trainer wrote that families using the autonomous mode use very little aid that does not originate from within the household (1978:236-7). Conversely, they argued the kinship mode makes extensive use of non-residential kin aid towards recovery, while the institutional mode consists of a high level of government assistance. Bates and Peacock argued that in the case of indigenous or independent recovery, aid "originates from within the boundaries of the victims' social unit 
itself." On the other hand, when aid originates beyond this unit it should be characterized as exogenous or dependent recovery (1989:359). Although there are differences in their approaches, all the researchers concur on the fact that a combination of modes are typically used to attain recovery.

\section{Community Context}

The goal of this research was to document the recovery of a sample of Hispanic households following Hurricane Andrew. In order to understand the processes involved in this recovery, it is necessary to review past research in three critical areas: household recovery, urban kinship, and the Cuban enclave. These three issues must be addressed because I believe they are all implicated in any effort to understand the recovery of the participating households in the present instance.

In a paper published in 1962, Reuben Hill and Donald A. Hansen conceptualized two "ideal" types of communities for their research on families affected by disasters. These two communities are the "kinship-oriented and the individuated" (Hill and Hansen 1962:200-1). According to the authors, the difference between the two types arises from the kind of relationships found between $\mathrm{kin}$ in each type of community. Thus, kinship-oriented communities are dominated by close family relations with little interaction existing between 
neighbors. Conversely, the individuated communities exhibit a predominance of nuclear families who do not have close relations within the family, but who maintain active relations with neighbors and friends; in other words, the relations between the members who form nuclear families are not very intimate and they do not often participate in activities together. The individuated type is overwhelmingly represented by urban, industrialized communities, while the kinshiporiented type is typically found in rural communities.

As would be expected in the wake of a disaster, in kinship-oriented communities aid is mostly directed towards relatives as opposed to the situation in individuated communities where aid is largely given to neighbors and friends. If Hill and Hansen had ended their argument at this point one would be led to believe that urban residents relied little on kin aid to recover after a disaster. However, a very important point the authors made in this study was that even in individuated communities the extended family still served a critical function for both short and long-term recovery (p. 202).

Since the present research deals with recovery among households that were located in an urban environment this last point is very significant. Exactly how critical is it for urban households to receive kin assistance towards their recovery? The answer appears to be that if it is not critical 
it is at the very least highly significant. Along this line, several researchers have documented the important role played by urban residents in assisting kin who are victims of a disaster, and who are urban residents themselves, recover.

Wallace, for example, found that in the aftermath of the 1953 Worcester (Massachusetts) tornado numerous individuals provided assistance to both relatives and friends (1956a:94). This aid amounted to what wallace described as "essentially welfare services" such as providing shelter for victims of the tornado. ${ }^{2}$ Similarly, Quarantelli (1960) found that urban inhabitants turned to the extended family as the primary source of aid and help during the warning period and immediately following impact. Moreover, he argued that victims first turned to family members and close friends, followed by less intimate friends, then neighbors, and finally, to strangers (i.e., co-ethnics) and organizations (i.e., government agencies and NGOs) (pp.263-264). Elsewhere, Drabek et al., (1975:491), through work with victims of a tornado that struck Topeka (Kansas) in 1966, found that kin ties are critical towards achieving recovery following a disaster. In fact, even in cases were pre-impact ties had not been strong, kin assistance towards recovery was still primary. In a related study by Erickson et al., (1976:205) with the victims of this same tornado, the authors reported that $54 \%$ of affected families received kin aid. Still other 
researchers, Neal et al., (1988:369), state that some 70\% of Bowling Green (Ohio) residents contacted family as the first source of help when stranded during severe winter conditions.

This is part and parcel of the general relationship identified among kin in an urban setting. Thus, in a study of urban working-class people in New Haven, Connecticut it was found that extended kinship plays a very important role in providing companionship and recreational partners throughout the lives of these individuals (Dotson 1951:693). Furthermore, this research also reported that a majority of married couples had no close relations outside the kin group. Likewise, Adams (1968:3) identified some primary social relationships as being provided by the kin network. More specifically, while friends and neighbors provided some intimate relations an equal or perhaps greater amount was provided by kin.

In their work with urban migrants, Graves and Graves note the importance of kinship ties in various aspects of urban life, for example, in finding housing and employment (1974: 129-131; 1980:196). Other research argues that informal networks between extended kin, such as trade and mutual aid, serve an important role in industrial societies (Gaughan and Ferman 1987:15). In other words, relatives exchange and provide each other with things that are needed as well as helping each other with work around the house. Furthermore, 
these "networks" exist among all social classes and help to alleviate a downturn in economic standing (p. 21). This last point is important since perhaps one would not expect to find these networks among the higher economic groups. Elsewhere however, Williams (1991:242) does argue that Anglos belonging to lower income groups do perform tasks for kin more often than do those belonging to higher income groups. Regardless, it does appear that generally urban individuals do provide substantial assistance for kin at all times. However, since this project deals with Hispanic households it is important to specifically look at kin relations among this group.

This is to some extent made simple since several researchers (Becerra 1983, 1988; Choldin 1973; Graves and Graves 1974, 1980; Keefe 1979, 1980; Mirande 1985; Moore 1971; Muller et al., 1985; Sánchez-Ayéndez 1988; Szapocznik and Hernandez 1988; Williams 1991) have written on urban kinship among Hispanic groups. A general theme that is found throughout this research is the importance of extended kinship ties for Hispanics. For example, Williams (1991:242), in work among Mexican-Americans, found that over 30\% of them "provided human care and transportation for family members on a weekly or monthly basis." Additionally, she reports that $14 \%$ of those belonging to high income groups performed unpaid home maintenance for members of their extended kin network. Likewise, Becerra $(1988: 150)$ writes that "... the family is 
viewed as a warm and nurturing institution for most Mexican Americans," which fits with a tendency to provide aid during hard times. Kin provide a broad range of goods and services for each other like child care, provisional shelter, care during illness, advice, and emotional support. Elsewhere, it is reported that financial dependence on kin was not reduced with the length of time Mexican Americans resided in Los Angeles, even for those who were second generation (Moore 1971:300). Finally, in writing on the Puerto Rican family, Sánchez-Ayéndez (1988:177) argues that kin ties are powerful and that interaction with kin occurs often. As a result, kin among Puerto Ricans are the prime source of support and generally represent a strong source for exchange of goods and services. Overwhelmingly, research points to the importance of extended kinship among Hispanic groups. However, extended kinship should not be confused with the extended family. In extended kinship, family members who do not reside in the same household (i.e., physical structure) have close relationships. Conversely, an extended family implies married siblings and their spouses living in the same housing unit.

There are, however, arguments to the contrary (Alvirez, Bean, and Williams 1981; Fitzpatrick 1981; Szapocznik and Hernandez 1988) though few in comparison to the positive ones. While briefly mentioning two of these, one (Szapocznik and Hernandez 1988) is worth a closer look since it is the only 
research on this topic that addresses one of the ethnic groups included in this research, namely cubans. According to these authors, "the traditional cuban family had already begun its transition from extended to nuclear family prior to the massive migration that began in 1959." Yet, they argued relatives and padrinos ("godparents") still play important roles in the family $(1988: 165)$. The implication is that Cubans do not rely on extended kinship to the same extent as do other Hispanic groups. Nevertheless, the Florida International University Disaster Research Team's (1992) phone survey, undertaken by the Institute for Public Opinion Research, of 1300 Dade households found that Cuban households tended to be part of extended kinship networks (Peacock and Morrow n.d.:7) . Finally, two critical issues to remember in the recovery of the four households that participated in this study is their ethnic and economic background. In other words, the ethnic background of all four households is Hispanic and their economic background is working class. Furthermore, all four households come from Latin countries where urban environments are not as distinct and separate from rural environments as is usually the case in the United Sates and, as such, working class individuals have skills not normally found among members of other economic classes in their countries or the United states. Moreover, these skills are not as widespread among working class households in the United States whose national 
origin is American.

In light of these facts, it is not unusual or surprising that the members of these households, as well as their nonresidential relatives, have carpentry skills that would enable them to rebuild their own dwellings. Because of these facts, South Miami Heights is not representative of other neighborhoods in South Florida, Westchester and Kendall for example, where, even though the populations are heavily Hispanic, the middle class backgrounds of the residents do not engender them to obtain these skills whether their background is Hispanic or not.

\section{Types of Aid}

Turning once more to household recovery, the types of aid that are provided by kin is an important aspect that merits more attention. Temporary shelter is one of the primary forms of assistance that is offered by kin to victims of a disaster. Many researchers (Bolin and Trainer 1978; Drabek and Boggs 1968; Drabek and Key 1984; Erickson et al., 1976) have reported that shelter is the predominant type of aid that individuals provide for kin affected by a disaster. In this vein, Drabek and Key (1984:90) reported that 67\% of disaster victims were temporarily housed by relatives in the wake of the 1966 Topeka (Kansas) tornado. Certainly, propinquity must be considered as victims who have kin living in the same 
vicinity, if themselves unaffected by the disaster, are more likely to be offered and accept temporary shelter than victims who live in another city for example.

Erickson et al., (1976:209) found that following temporary shelter, food and clothing, obvious necessities, were the next type of aid most often offered to disaster victims by their relatives. However, it should be remembered that an offer of temporary shelter most likely will include food and clothing, if needed. Beyond these types of aid there are numerous others such as transportation and different forms of personal assistance. A final one worth mentioning is economic aid. While it has been documented that some kin do provide loans, this is apparently rare. Financial help such as loans did not come primarily from kin, but from other sources (Erickson et al., 1976:209). In fact, kin aid is usually limited to non-financial help (Rossi et al., 1983).

\section{Minorities in Disaster}

While all groups can be affected by a disaster, it generally takes a special toll on minorities. Bolin and Stanford (1991:27) argued that the homes of lower income victims suffered disproportionate damage as a result of an earthquake that struck Coalinga, California. Furthermore, "a disproportionate number of these victims were Hispanics (Mexican-Americans)." As a result, they argued it was much 
more difficult for Hispanic victims than for Anglo victims to reestablish permanent housing. This theme is repeated by other researchers who reported similar findings (Bolin and Bolton 1986; Perry and Mushkatel 1986; Phillips 1993).

It must be remembered, however, that in the present case, it is problematic to consider Cubans in Miami a minority, either numerically or in ready access to resources that are denied minorities in other settings (Grenier and stepick 1992:7-9). However, the non-Cuban Hispanic households may prove a better fit in the findings of disaster studies dealing with minorities since in Miami minority issues are wholly applicable to these other Hispanic groups. This is the crux of the "enclave" issue in Miami.

There can be very little doubt that the Cuban enclave in Miami provides Cuban households in the area with numerous advantages as compared to non-Cuban Hispanic households. However, did these advantages materialize during the recovery that took place after Hurricane Andrew? Were Cuban households able to utilize the enclave to assist them in their recovery? While this seems highly unlikely, it may be that non-Cuban Hispanic households were also able to acquire assistance from the enclave in their recovery efforts following the storm. The following chapters attempt to answer these questions through a qualitative study of the four households that took part in this project. 


\section{THE STUDY}

\section{The Case Study: Anthony F.C. Wallace's Theory}

In discussing South Miami Heights it is important not only to describe the area as it was in the aftermath of the storm in August of 1993 and 1994, but to provide a description of this suburb prior to the devastation caused by Hurricane Andrew. This is necessary because of the changes that this area experienced as a result of the storm. These changes ranged from massive reconstruction to simply having to buy groceries at another supermarket. The description of South Miami Heights prior to the storm will be based on the definition of the pre-warning period (i.e., the time prior to the warning of an impending disaster being issued), which precedes any disaster, as formulated by Anthony F.C. Wallace.

In 1956 Wallace's longitudinal disaster study on the tornado that struck Worcester (Massachusetts) in June of 1953 was published. This work was a milestone in disaster studies as it was the first, to my knowledge, that plotted out a disaster as a time-space model. In other words, Wallace looked at disasters as temporal events that encompassed the period prior to the warning being issued to the period following the disaster (i.e., recovery period). BY conceptualizing the study of disaster in this manner, Wallace was able to demarcate specific temporal segments which 
permitted in-depth exploration of all phases of a disaster. The part of Wallace's formulation which is critical for the present section of this study is the one designating the period just before the warning of an impending disaster is issued.

Wallace named the period prior to a warning being issued the "steady state" (Wallace 1956a). As defined by Wallace, the steady state is:

... the system of regular energy-distribution (action) obtaining in all of the ultimately affected areas at the moment just preceding the warning period. The system will probably [emphasis added] be in equilibrium, or nearly so, at the time of any given disaster. By equilibrium I mean that energy discharges are of a repetitive and predictable nature, in response to chronic stresses; furthermore, such stresses are eliciting effective conventional responses. In other words, the cultural system, and the personalities of the population, are operating sufficiently smoothly to obtain stress reductions for the population, such that the total quantity of stress in the area at large is not systematically increasing or decreasing (although there will be random variation).

... both the total system and the momentary situation at the moment of warning, threat, or impact are important determinants of what happens as the disaster proceeds.

Wallace expanded his concept of the "steady state" in a paper on revitalization movements (1956b). According to Wallace, in the "steady state:"

For the vast majority of the population, culturally recognized techniques for satisfying needs operate with such efficiency that chronic stress within the system varies within tolerable limits. 
Although Wallace applied his concept of the "steady state" to Worcester (Massachusetts) in this instant, a unit of analysis much larger and clearly defined than the neighborhood of South Miami Heights, his theory is nevertheless applicable to all units of analysis ranging from individuals to entire cultures. Wallace (1962), for example, applied this concept to individual human beings in discussing what he called the "mazeway." According to Wallace, the "mazeway" for an individual consisted of "... a complex system of objects, dynamically interrelated, which includes the body in which the brain is housed, various other surrounding things, and sometimes the brain itself" (1962:16).

In the act of leading their daily lives, individuals function in a "steady state" in which the "mazeway" acts and is acted upon by numerous things. The "steady state" for individuals is maintained as long as stresses which are placed upon them are capable of being handled through conventional responses $(p, 20)$. If it is not possible to handle stress through conventional responses, it is possible that an individual will have a nervous breakdown, for example. The point I am trying to make here, however, is that wallace's concept of the "steady state" is applicable to South Miami Heights as a unit of analysis since wallace himself successfully applied it to numerous entities of various dimensions and social structures, such as the Delaware and 
Seneca Indian Nations (1956c; 1972).

\section{The Context}

South Florida can roughly be demarcated as starting at the southern end of Lake okeechobee and running south from there to Key West, an area comprised of six counties. Four of the six counties, Broward, Collier, Hendry, and Palm Beach, suffered little or no damages, a fifth, Monroe County, suffered moderate storm damage. The sixth, Dade County, suffered the heaviest damage by far as its southern end was nearly leveled by Andrew. This part of Dade County includes sections of Miami and cities like Homestead and Florida City.

Within the city of Miami, for example, there are both incorporated and unincorporated zones (Figure 2). Incorporated cities like South Miami have their own charter, city hall, and police and fire departments. Unincorporated areas, like Perrine, Goulds, and South Miami Heights, the focus of this study, are dependent on Dade County municipal government for the services provided by these agencies and numerous others.

For the moment, concentrating on Dade county as a whole, the worse damage overall occurred roughly south of Kendall Drive (S.W. 88th Street) (Figure 2). Among the many neighborhoods located in this area is the Miami suburb of South Miami Heights. This suburb, while not in Andrew's 


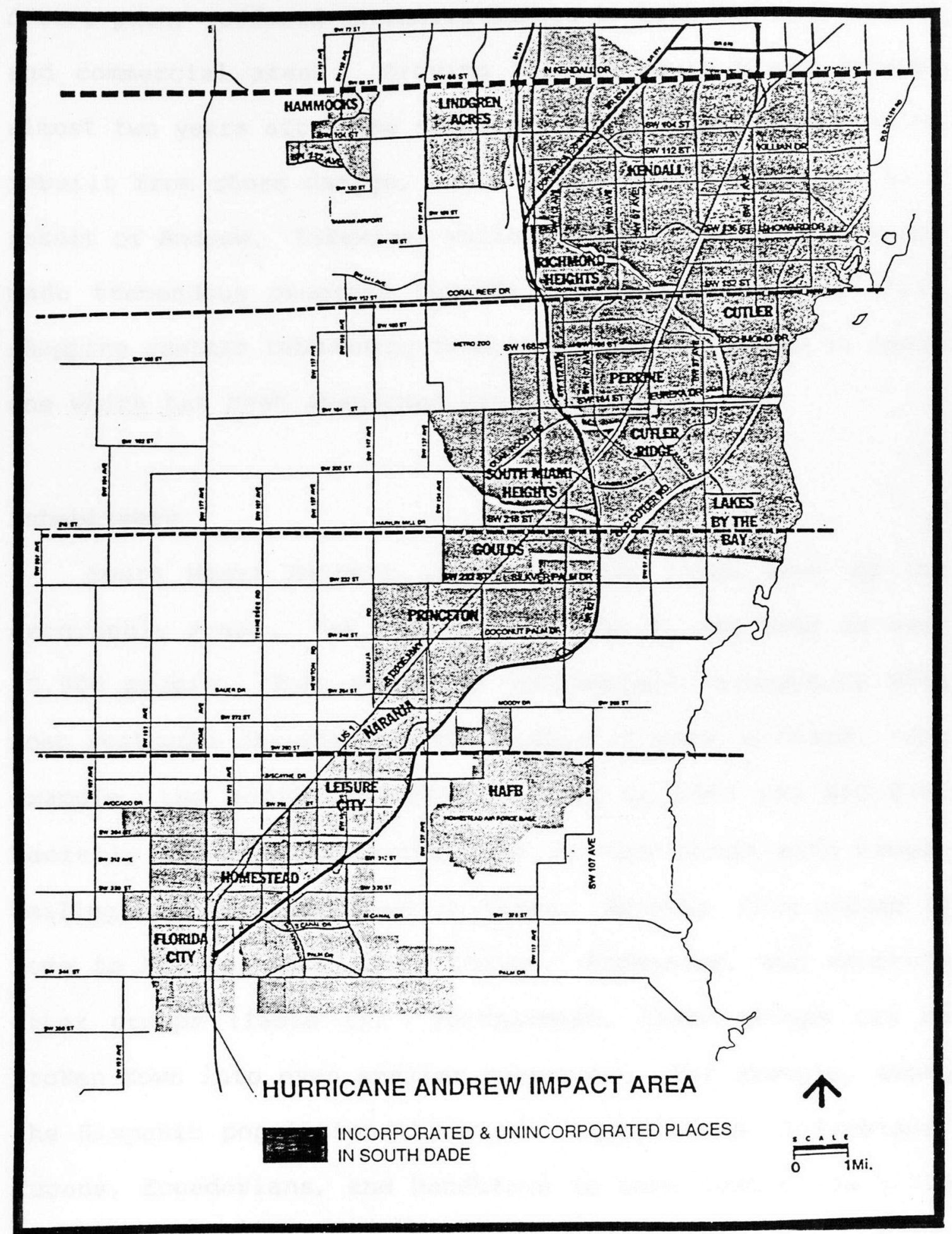

Source: Metro-Dade County Planning Department

Figure 2

Incorporated and unincorporated areas in South Dade. 
direct path, suffered extensive damage to both its residential and commercial areas. Driving through South Miami Heights almost two years after the storm one still found houses being rebuilt from storm damage, while others stood abandoned as a result of Andrew. Likewise, while the commercial district had made tremendous progress towards recovery there were still shopping centers rebuilding from hurricane damage and at least one which had been abandoned since the storm.

\section{Inhabitants}

South Miami Heights is not a very large area in the geographic sense. Yet, prior to Andrew it was home to over 30,000 people. This suburb is economically homogenous with most residents falling into the middle or working class. For example, the median household income in 1989 was $\$ 28,870$. Racially and ethnically the area is very mixed with people hailing from many different cultures. Briefly, this suburb is home to African Americans, Anglos, ${ }^{3}$ Hispanics, and numerous other groups (Table 1). Furthermore, these groups can be broken down into even smaller subgroups. For example, among the Hispanic population there are Argentineans, Colombians, Cubans, Ecuadorians, and Hondurans to name just a few (1990 U.S. Census) (Table 2). Moreover, the racial makeup of the population is also diverse (Table 1 ). The 1990 census lists whites, blacks, Native Americans, and Asians, for example, 
Table 1

South Miami Heights' and Dade County's population by origin and racial group.

\begin{tabular}{|c|c|c|}
\hline Racial Group & South Miami Heights (을 & Dade county $\left(\frac{\circ}{0}\right)$ \\
\hline \multicolumn{3}{|l|}{ Non-Hispanic Origin } \\
\hline Asian or Pacific & & \\
\hline Islander & 2.2 & 1.2 \\
\hline Black & 26.4 & 19.2 \\
\hline Native American & 0.3 & 0.1 \\
\hline White & 22.8 & 30.4 \\
\hline Other & 0.25 & 0.1 \\
\hline Total & $\begin{array}{c}52.0 \\
(n=15,531)\end{array}$ & $\begin{array}{c}51.0 \\
(n=987,394)\end{array}$ \\
\hline \multicolumn{3}{|l|}{ Hispanic Origin } \\
\hline Asian or Pacific & & \\
\hline Islander & 0.2 & 0.1 \\
\hline Black & 1.7 & 1.4 \\
\hline White & 40.0 & 42.7 \\
\hline Other & 6.1 & 4.8 \\
\hline Total & $\begin{array}{c}48.0 \\
(\mathrm{n}=14,499)\end{array}$ & $\begin{array}{c}49.0 \\
(n=949,700)\end{array}$ \\
\hline TOTAL & $(n=30,030)$ & $(n=1,937,094)$ \\
\hline
\end{tabular}

as living in the area.

For these reasons and others mentioned in previous sections, South Miami Heights presented an opportunity to explore different aspects of recovery following a major natural disaster; specifically, an opportunity to explore recovery among both Cuban and non-Cuban Hispanic households. 


\section{Table 2}

Breakdown of 1990 South Miami Heights' Hispanic population by nationality compared with that of Dade County.

\begin{tabular}{lcc}
\hline Nationality & South Miami Heights $\left(\frac{\circ}{\circ}\right)$ & Dade County $\left(\frac{0}{\circ}\right)$ \\
\hline Colombian & 7.0 & 6.0 \\
Cuban & 51.0 & 59.0 \\
Dominican & 5.0 & 2.5 \\
Ecuadorian & 0.5 & 0.8 \\
Guatemalan & 0.7 & 0.9 \\
Honduran & 2.4 & 2.0 \\
Mexican & 4.0 & 2.4 \\
Nicaraguan & 4.0 & 7.8 \\
Panamanian & 0.7 & 1.7 \\
Peruvian & 2.0 & 0.7 \\
Puerto Rican & 16.0 & 7.0 \\
Salvadorian & 1.3 & 0.8 \\
Other Hispanics & 5.0 & 8.0 \\
Total Hispanic Population & 48.0 & 49.0 \\
\multicolumn{2}{c}{ (n=14,499) } & $(\mathrm{n}=949,700)$ \\
Source: 1990 U.S. Census of Population and Housing &
\end{tabular}

Additionally, it allowed comparison between households that were similar in some important aspects such as education and income level.

\section{Steady State: South Miami Heights Before Andrew}

South Miami Heights is an unincorporated neighborhood that is located towards the southern end of Metropolitan Dade County about thirty-five miles south of downtown Miami via the Dolphin Expressway and the Florida Turnpike. It is a small community in the geographic sense, surrounded by similar suburbs like Cutler Ridge, Goulds, Perrine, and Richmond Heights. As an unincorporated suburb of Miami, South Miami 
Heights does not have any of the amenities of an incorporated city. In other words, there is no local government and the matters normally handled by local officials fall under the jurisdiction of Miami City Hall located several miles to the north in Coconut Grove. Accordingly, the local police and fire departments, as well as other local government agencies, are under the supervision of Metro-Dade County government. Yet, lack of self government does not seem to have hindered its growth as the population increased by close to 3000 people between 1985 and 1990, which is probably lower than the actual number (1990 U.S. Census). Similarly, commercial growth appears to have taken place during this period as prior to the hurricane new shopping centers were built to serve the residents. ${ }^{4}$

Much like other suburbs in Miami, South Miami Heights is not a place where one goes incidentally. Unless one resides there or has some business in the area, whether social or commercial, there is nothing significant to draw people to the area. This is not to say that it is unattractive, on the contrary, there are some very nice homes along with a few public parks that add a touch of character to the area. While South Miami Heights itself is not an attraction it is located in an area through which millions pass every year. Located at its northern end is the Metro-Dade Zoo, which draws thousands of visitors each month. Its eastern boundary is U.S. 1 which 
handles thousands of travellers every day, and slightly east of this boundary is the Florida Turnpike which is the throughway for countless individuals heading north and south on a daily commute.

Like the rest of South Florida, South Miami Heights is located in a very flat area and the only high ground found in this suburb likely results from the improper paving of roads. Even though there are a few parks in the area, not one has a lake or even a pond. In truth, these parks are more like asphalt playgrounds with grass and trees added to soften their appearance and make them more attractive. The only body of water found in the area is Black Creek Canal which runs along the southern portion of the area (Figure 3 ). This canal is typical of side water courses in South Florida in that it is not a natural feature but man made. ${ }^{5}$

A particularly noticeable trait about this suburb is the vacant and overgrown land that is scattered throughout it. Driving through the area one cannot help but notice the amount of land, whether government or privately owned, that sits desolate and weed-infested long after losing whatever natural beauty it had. This open land bakes under the heat of the Florida sun for most of the year or turns to muddy temporary marshes whenever it rains heavily.

While there are several main arteries that provide easy access to numerous parts of the suburb or through it, leaving 
these roads proves to be perplexing. In one especially frustrating zone, streets and avenues criss-cross each other at odd angles and take unexpected turns. Not only is it confusing for those unfamiliar with the area but also dangerous as quick stops are made to check directions and stop signs are occasionally missed. Another local feature, which is not restricted to South Miami Heights in South Florida, is the presence of walled communities. Usually these communities have one, two, or at the most three avenues by which to enter and exit. Whether intended or not, the limited access to and from these areas tends to discourage those unfamiliar with them from searching out an address.

Ecologically this suburb is very similar to others in South Florida of the same class and income level. Virtually the whole area is dedicated to single family homes with several duplexes, i.e., two houses with a common wall dividing them, scattered throughout. The vast majority of the homes are modest middle or working class houses. These will perhaps have a 60 by 40 foot backyard and a much smaller side-yard if they have one at all. While there are some dwellings that could be designated as upper-middle class these are very few and only found by the western boundary in an area south of Metro-Dade Zoo. There are also several multi-family dwelling units to be found in the area. These are either very large buildings which all together house hundreds of families or 
condominium townhomes with each condominium development perhaps housing thirty to forty families.

At the time of this research, there were two commercial zones to be found in the area (Figure 3). One was located on South Dixie Highway, also known as U.S. 1, which roughly constituted the eastern boundary of South Miami Heights. The section of this commercial zone which fell within the boundaries of this suburb was very small but appeared to be significant in terms of the number of businesses found there and the almost constant bustle after the businesses reopened following the storm. The other zone was located on Quail Roost Drive and stretched in a southwesterly direction starting at Southwest (S.W.) 117th Avenue. Quail Roost Plaza, was the largest shopping center in South Miami Heights and contained a wide variety of businesses ranging from fast food restaurants like Burger King and Pizza Hut to distinctly ethnic businesses.

In 1992 there were a total of 594 businesses located in South Miami Heights. The types of business ventures ranged from 160 in construction to a single one, discussed below, that was involved in mining. There were 68 businesses practicing some type of retail trade along with 62 involved in wholesale trade. Enterprises providing some type of business service were well represented with 119 to be found (Table 3). Also worth mentioning is the presence of a sewage treatment 


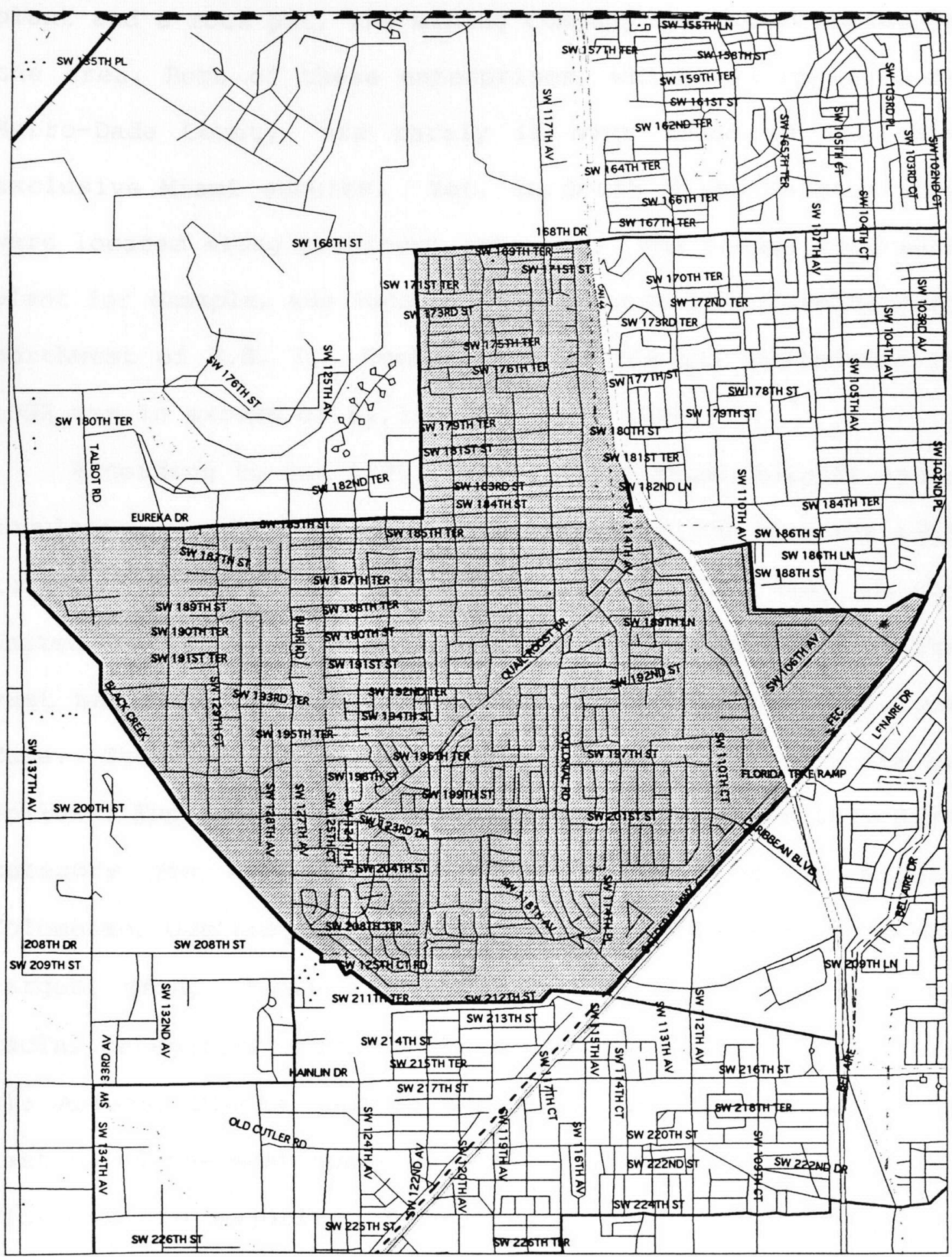

Source: Federal Emergency Management Agency

Figure 3

South Miami Heights. 
plant and a rock pit, the mining company mentioned above, in the area. Both of these enterprises, which are operated by Metro-Dade County, are rarely if ever found in the more exclusive Miami suburbs. Yet, in South Miami Heights they were located along prominent arteries. The sewage treatment plant for example, was located on southwest 117 th avenue just northwest of U.S. 1. Combined sales for all businesses in 1992 was in excess of $\$ 1,300,000$ (FEMA 1994).

According to the 1990 Census, South Miami Heights had a population of 30,030, an increase of almost 10\% from the 1985 total of $27,318.6$ of this population $61 \%$ were born in the United States and 39\% were foreign born. Overwhelmingly, the vast majority of those classified as foreign born are from Cuba. The major ethnic categories of the inhabitants are as follows: English, German, Irish, and Hispanic. In this last category you have various nationalities such as Cuban, Colombian, Guatemalan, and Mexican with Cubans making up the largest group (Table 2). Breaking the population down by racial categories provides the following distribution (Table 1): Asians, Blacks, Native Americans, and whites, with the last being the most numerous. As might be expected in South Florida, the majority of residents speak Spanish at home followed closely by those who speak English (Table 4). Naturally, although the census does not report this, there are many households which speak both languages. There are also 


\section{Table 3}

Number of businesses in South Miami Heights involved in a particular enterprise in 1992 prior to Hurricane Andrew.

\begin{tabular}{lrc}
\hline Business Type & Number of Businesses & of \\
\hline Construction & 160 & 27.0 \\
Manufacturing & 51 & 8.6 \\
Wholesale Trade & 62 & 10.0 \\
Retail Trade & 68 & 11.0 \\
Business Services & 119 & 20.0 \\
Professional Services & 51 & 8.6 \\
Other & 83 & 14.0 \\
$\quad$ Total & 594 & 100 \\
\hline
\end{tabular}

Source: EEMA 1992 South Miami Heights Business Profile Report

households which speak other languages. However, the only one with a significant number are those that speak French or French Creole which can almost certainly be attributed to Haitian immigrants.

The households interviewed for this project gave various reasons for deciding to move to this area. For example, a 50 year old immigrant from Nicaragua, who had lived in this suburb since 1988, at first said that he did not know the area when he bought the house, but felt at the time that it seemed private. Later on in the interview though, he commented that he had previously lived in the Northwest ${ }^{7}$ section of Miami where his car had been stolen and so he moved to South Miami Heights because it had less crime. An immigrant from El Salvador bought a house in South Miami Heights in 1992, as luck would have it, a month prior to the hurricane, specifically because his mother had lived in the area since 


\section{Table 4}

Languages spoken at home in South Miami Heights and Dade County.

\begin{tabular}{lcc}
\hline Language & South Miami Heights $\left(\frac{\circ}{\circ}\right)$ & Dade County (ㅇ) \\
\hline English & 48 & 43 \\
Spanish & 49 & 50 \\
Other & 3 & 7 \\
$\quad$ Total & 100 & 100 \\
Total Population & $\mathrm{n}=30,030$ & $\mathrm{n}=1,937,094$ \\
\hline Source: 1990 U.S. Census of Population and Housing &
\end{tabular}

1973. The reasons given by the Cuban household, which had lived in the area for most of the last twenty-four years, were that they liked the area; it was cheaper to live than where they had previously lived, which was the Northwest section; the owner of the house where they had lived in the Northwest had asked them to move out; and finally, they noted that the schools in the area where they had previously lived were being racially integrated. As can be seen, reasons for moving to South Miami Heights ran from simply liking the area to attitudes about race and crime.

The educational attainment of the population 18 years of age or older varies with only about 23\% having continued beyond a high school education. Of these some 16\% or 1,090 individuals had earned a bachelor's or higher degree with a little less than half of these having gone on to a graduate or professional degree. About 47\% of non-high school graduates did not make it beyond the eighth grade with roughly 53\% of 
these reaching the 12th grade, but not earning a high school diploma. Students living in South Miami Heights, up through the senior high school level, attend one of three elementary schools, Miami Southridge Middle School, and Southridge Senior High School which serve the school district in which South Miami Heights is located. Although I do not know if it was ever necessary to integrate these schools, in 1994 people of all ethnic and racial groups attended them. Based on the interviews, I assume that at some point whites, whether Anglo or Hispanic, were predominant since the area was more to the liking of the Cuban household mentioned above which disliked the integration of the schools where they had previously lived.

Looking at occupations, this was a fairly diverse area with individuals working in jobs from the executive level to those who earned a living as laborers. The vast majority however, worked in service industries, mid-level administrative positions, or as skilled craftsman. of 21,927 individuals aged 16 years or older in 1990, 15,534 or some $70 \%$ were in the labor force with 15,421 or $99 \%$ of these in the civilian labor force and 113 in the armed forces, probably stationed at Homestead Air Force Base or the Coast Guard communication station located just north of South Miami Heights. ${ }^{8}$ The unemployment rate for the civilian labor force in 1990 was a relatively high $7.3 \frac{\circ}{9}$ 
Economically this appeared to be a relatively homogenous area with the majority of households falling into the working class or middle class. In other words, using a four class system, lower class, working class, middle class, and upper class, with some variation found in the middle class (i.e., upper middle class), most of the households in South Miami Heights ranged from working to middle class. For this study, working class was identified as households in which the individuals were employed or self-employed as laborers or skilled craftmen, for example. Middle class was identified as households in which the individuals were again, employed or self-employed, as accountants, in certain managerial positions, and so forth. Working class households greatly outnumber middle class ones. There were some lower-class households, generally single-parent homes with a female head. Finally, there were very few, probably no more than 30, upper middle-class households.

When driving through the area the class structure became obvious as most houses were quite modest single family homes or duplexes. I also found several similarly modest condominium townhomes and quite large apartment buildings, which were apparently maintained as low-cost housing. Undeniably, house owners vastly outnumber house renters in South Miami Heights. Thus, preliminary data from the 209 interviews conducted by the Florida International University 
Disaster Research Team in South Miami Heights, suggested that fewer than 5응 of those households were renters.

The median household income according to the 1990 Census was $\$ 28,870$ which is surprisingly high given the unpretentious look of the area. Though not documented, many, if not most, of the households probably had multiple-wage earners. In other words, most of these households had two and, in many cases, possibly more employed individuals contributing to the household income. This is especially true of Cuban Hispanic households as Pérez (1986) has reported. In other words, on the average, Cuban Hispanic households have more workers, particularly women, than other groups in the U.S. (Pérez $1986: 10,1992: 92)$.

Breaking household income down into racial categories, whites on the average earned more than blacks and Native Americans for example. Hispanic households predominantly earned incomes ranging from $\$ 15,000$ to $\$ 74,999$ with several earning less and very few above this. Median family income, which takes into account the income of individual families and so is different from household income because a household may consist of a single individual, one family and part of another, or perhaps two or more families, was slightly higher than median household income at $\$ 31,213$.

Poverty appeared and likely continues to be a serious problem in the area with just over $16 \%$ of the population, for 
which poverty was determined, reporting that they were below the poverty level. Thus, 13\% of families reported that they were below the poverty level with a very high $27.3 \%$ of femaleheaded families being impoverished. Obviously, even though the median household and family incomes were relatively high, there were a significant number of households and families living in poverty. The reason for the relatively high median incomes appears to be due to the poverty incomes being offset by the more prosperous members of the community.

This is a profile of South Miami Heights at the beginning of the final decade of the twentieth-century, which would hold more or less for another two years until Andrew devastated the area. As with Wallace's definition of the "steady state," everything functioned more or less in equilibrium as any stress that was placed upon the entire system could be handled through conventional means. While undeniably some individuals were unable to handle the stress placed upon them, whether routine or not, most did so successfully and no substantial

effect upon the larger system resulted from this quarter. As Wallace states, this "steady state" lasted until the time just before the warning period.

\section{Post Hurricane Andrew}

Unfortunately after Hurricane Andrew a census was not taken in South Miami Heights in order to detect the changes 
that had taken place. While some effects were very obvious, such as determining the number of buildings destroyed, some were not. For example, how many residents moved out of the area, how many were left unemployed, and did incomes fall and if so, how much? As mentioned previously, this research originated from a larger project that included a sample of 209 households and which gathered information related to Hurricane Andrew such as that discussed above. While the vast amount of information specifically relating to the households interviewed for that project and this one is presented later, some will appear here as I discuss South Miami Heights in general following the storm. In order to do this the time frame will be broken down into two periods. The first period will cover South Miami Heights about one year after the storm whereas the other will look at it almost two years after Andrew. These periods have been chosen because they accord with the author's most active research periods in the area.

South Miami Heights from May to August of 1993 was still an area very much on the mend. Everywhere one looked there was some type of construction going on, whether residential or commercial; being done by professionals, by people who called themselves professionals, or the property owners themselves. Some of it was major construction, while some was relatively minor when measured in the context of the damage suffered by other buildings. Several houses, condominiums, apartment 
buildings, and businesses appeared to have been abandoned as the damage inflicted upon them had been too great for any attempt at repairing or rebuilding. Piles of hurricane debris littered the streets throughout the entire suburb as MetroDade County had yet to mount a concentrated debris removal effort in the area.

Still, there was an air of determination as it appeared that most single family homes had been either completely rebuilt or close to it. In fact, some $70 \%$ of those interviewed by the Florida International University Disaster Research Team almost a year after Andrew reported that 90\% or more of their home had been repaired. This high percentage loses some of its luster however, as over $17 \%$ were still rebuilding and a vacancy rate estimated to be exactly $40 \%$ persisted in South Miami Heights nine months after Andrew (Peacock and Morrow 1993:6). The later figure resulted primarily because of the lack of repair or reconstruction that was taking place on multi-family dwelling units. Obviously, there were critical recovery needs that had yet to be addressed in South Miami Heights at this time.

On an individual basis, a review of the South Miami Heights Survey showed that respondents gave various answers as to what they thought were the most pressing unmet needs in the area at this time. One answered that debris clearance and children's activities, meaning that the local playgrounds were 
still in disrepair, had received no attention. Another said that shopping centers and movie theaters were needed as few if any had been repaired or rebuilt. According to one individual, gas prices were too high and that this was not fair because people had lost so much. In several cases the answer related to one particular shopping center located on Quail Roost Drive and S.W. 200th Street. ${ }^{10}$ Having been completely destroyed by the storm, it was abandoned and had turned into a youth gang hangout which worried many of the households residing near by. Conversely, others responded that everything had returned to normal, there were no unmet needs, or that they could not think of any. Why did some people find unmet needs while others did not? One possibility is that those who had no unmet needs had, by the time of the first survey, nearly or completely finished repairing or perhaps rebuilding their house. Whatever the reasons, it is safe to say that, nearly a year after Andrew, South Miami Heights still had a long road ahead towards achieving full recovery.

One of the areas where this was most obvious was the business sector. While prior to Andrew, in 1992, there were 594 businesses located in South Miami Heights, in 1993 this number was reduced by 13\%. In other words, South Miami Heights had 79 fewer businesses following the hurricane. However, it must be noted that not all of these went out of 
business, many likely relocated because the rebuilding costs or new insurance rates may have been too high. The total number of workers employed in the area went down from 7146 in 1992 to 4014 in 1993, a reduction of $44 \%$. Possibly the most dramatic drop occurred in business income. Sales went down from over $\$ 1,300,000$ to $\$ 228,370 ;$ a loss of over $\$ 1,000,000$ or 82\%. Perhaps not surprisingly, construction companies suffered the smallest loss, less than 16\%, while finance, insurance, and real estate companies earned some 99\% less in 1993 than they had in 1992 (FEMA 1994).

Almost two years after the storm, things improved dramatically. In driving through the area one could still see homes and businesses being rebuilt, but these were relatively few. Moreover, of the few that were being rebuilt most appeared to need only minor work. Most of the debris appeared to have been cleared since only very small piles were infrequently seen scattered throughout the area. Furthermore, the vast majority of businesses appeared to be open as they had been the previous year. The main shopping center in the area, Quail Roost Plaza, appeared to have almost fully recovered as shoppers abounded even on weekdays. Similarly, the commercial zone on U.S. 1 looked prosperous; every time I drove by it the many businesses were full of clients. Additionally, the concern of one respondent in the first survey, regarding unmet needs, appeared to have been satisfied 
as playgrounds throughout the area had been repaired and opened.

However, this is not to say that everything was as it had been prior to Andrew. For example, the shopping center located on Quail Roost Drive and 200th street that worried so many nearby residents, while generally being cleared of debris had been completely boarded up and did not look to fit into anyone's immediate plans. Likewise, a Rose Auto Store located at the Quail Roost Plaza occupied a double trailer as the empty shell of the building that previously housed it awaited demolition. There were also several houses throughout the area that had been abandoned. Some had been completely boarded; others, like the one that was next to the Mexican household interviewed for the present research, were merely walls with little or no roof covering their gutted interiors. Thus, while South Miami Heights appeared to have basically recovered, there were still prominent signs of Andrew's destruction.

\section{The Four Hispanic Households ${ }^{11}$}

The households that participated in this research were all of Hispanic origin and were residents of South Miami Heights at the time of Andrew's impact on August 24, 1992. The national-origin identities of the households is as follows: one was Cuban, one was Mexican, one was Nicaraguan, 
and one was Salvadorian.

At the individual level, it is important to note, however, that in the Nicaraguan household only the adult male was born in Nicaragua, while the other family members were born either in Honduras or the United States. Likewise, in the Salvadorian household only the adult male was born in El Salvador, while the rest were born in the United States. Nevertheless, both households gave the national origin of the adult male as the primary one. In other words, both households identified with the adult male head of household's national background.

One reason for this, of course, may be that in each case the interviewee was the adult male. Perhaps if the adult female had been interviewed the national origin each household reported would have been that of this individual. It is worth pointing out that each household did specifically identify itself as Hispanic in the first survey. This should not be taken to mean however, that the households believed there was an identifiable overarching Hispanic identity which supplanted their individual national backgrounds. In other words, the households did not identify themselves as solely Hispanic. On the contrary, each household specifically identified itself as Cuban, Mexican, Nicaraguan, or Salvadorian.

This is not surprising in light of the fact that numerous researchers (Calderon 1992; Chavez 1994; Felix-Ortiz et al., 
1994; Porter and Washington 1993; Rodriguez 1994; Shoriss 1992) have documented the diverse ethnic and national identities maintained by Hispanic groups in the United States. In other words, while other Americans may lump all groups descended from Latin American or Spanish-speaking Caribbean origins under the definition of Hispanic, this is not always the case for these individuals themselves when they are living in an area where there are numerous other Hispanic groups. On the contrary, individuals with a Hispanic background living in such an environment (i.e., Miami or Los Angeles) often identify themselves by their specific national origin. Conversely, Hispanic is often the self-identification of such individuals when living in an area where individuals with a Hispanic background are few.

The number of individuals contained in each household varied. Of the four, the one with the fewest members was the Cuban household which reported only two members. Nevertheless, on all the occasions that I visited them, three of their grandchildren were there. This was also the household with the oldest members, the male being 62 and the female 58 at the time of the second survey. Both the Nicaraguan and Salvadorian households contained five members. In the Nicaraguan household the adult male was 50, the adult female 34, and the three younger female members were 12, eight, and six years of age at the time of the second survey. As for the 
Salvadorian household, the adult male was 35, the adult female 29, one younger male 10 and the other eight, while the younger female member was six at the time of the second survey. Finally, the Mexican household contained seven members. At the time of the second survey, the oldest adult male was 50, the oldest adult female 45, one younger female member 24, one 23 and the other 18. As for the younger males, one was 21 and the other 10 .

Stated dates of immigration to the United States was different for each household. Looking at them chronologically, from earliest to most recent, as might be expected, the Cuban household reported the earliest arrival date (1966), with both individuals being born in Cuba. The next to arrive was the adult male of the Salvadorian household, who arrived in 1980 having been born in El Salvador. The other members were born in the United States. Following this, is the Nicaraguan household with the three foreign-born members arriving in 1982 and 1983. Specifically, the adult male, who was born in Nicaragua, arrived in 1982 . The adult female and oldest daughter, both born in Honduras, reached the United States one year later. As for the Mexican household, all the males arrived in 1986 followed by all the female members in 1988. Every member of this household was born in Mexico.

Regardless of arrival date or place of birth, all four 
households reported Spanish as the language most often spoken at home. Still, in two of the households, the Nicaraguan and Salvadorian ones, I observed that English was frequently used by some of the younger members to converse among themselves or with their parents. Conversely, in the Cuban and Mexican households, English was never used in my presence. While it is likely that the younger members of the Mexican household speak English it is probable that it was not used at home, even among themselves unless perhaps they were alone, since their parents only spoke Spanish.

of the four households, three of them settled directly in South Florida upon arriving in the United States. The only one that did not fully settle in South Florida was the Mexican one with the males, including the youngest, all having lived in Pennsylvania and South Carolina prior to joining the female members in South Florida in 1988. While the Cuban household did settle in South Florida after having arrived from Cuba in 1966, they also lived in Houston (Texas) from 1979 through 1987.

Looking at when residence was taken up in South Miami Heights, the only household to have solely lived in south Miami Heights since moving to South Florida is the Salvadorian household which purchased a house in the area in July 1992 just a month before Hurricane Andrew struck. Prior to moving to South Miami Heights in 1988 the Mexican household lived in 
Homestead, which is located several miles to the south. The Nicaraguan household lived in the Northwest section of Miami before moving to South Miami Heights also in 1988. Finally, the Cuban household also resided in the Northwest section of Miami before moving to South Miami Heights in 1970 and, as mentioned above, they had lived in Houston for eight years from 1979-1987. Unlike two of the other households however, the Cuban one did not own the house, which they moved into when first taking up residence in the area. Prior to purchasing a house in the area in 1971, they rented two in South Miami Heights. Likewise, the Salvadorian household lived with the household head's mother for several years prior to purchasing a house in the area. Unlike other neighborhoods in South Florida, Little Havana for example, South Miami Heights does not appear to be a place were newly arrived immigrants take up residence. The only household to locate directly in South Miami Heights, upon arriving in the United States, was the Salvadorian one and this likely occurred because the adult male's mother had lived there for many years.

The respondents gave various answers to a query about their reasons for moving to South Miami Heights. The Cuban household cited several reasons for taking up residence in the area. These range from liking the area to the fact that during the late 1960s and early 1970s the schools in the Northwest 
section where they lived were being integrated. The Nicaraguan household stated at first that they had just simply liked the area. Upon further probing however, they did state that the crime rate in the area when they first started looking for a house there appeared to be lower than where they had lived before. The Salvadorian household simply moved here because the mother of the adult male had lived in South Miami Heights since 1973 and they wanted to be near her. Lastly, the Mexican household moved here because it was near to where members of the household were employed.

All four households were content with their decision to move to South Miami Heights at the time of the second interview despite the fact that they had all suffered to some extent because of Andrew. Reasons given for this contentment were often similar. For example, a low crime rate, the fact that the area was calm, and there were very few problems (i.e., automobile traffic, noisy neighbors). However, some of the answers were surprising. The Cuban household pointed out the fact that, in their opinion, Blacks down here (i.e., South Miami Heights as opposed to areas north of it) did not riot and they were more decent. The Mexican household stated that in South Miami Heights the house belonged to them and not to someone else.

In discussing what they did not like about living in South Miami Heights at this time the respondents gave the 
following answers. The Cuban household said that South Miami Heights was not like it used to be. According to them there were a lot of different immigrants in the area now. As for the Nicaraguan household, the fact that a center for abused children was possibly coming to the neighborhood worried them. The reason they stated for not liking this was because, in their opinion, these people are or will be supported by the government and therefore, they were not "productive" individuals. As for the Salvadorian household, the interviewee said that "blacks" worried him. However, he then said it was a joke because people would think he was a racist otherwise. The Mexican household said there was nothing they disliked about South Miami Heights at the time of the second interview.

Educational attainment varied among the adult (i.e., 18 years of age or older) members of some of the households but was in general accord with that discussed for South Miami Heights as a whole previously. Both members of the Cuban household while not graduating from the instituto, as high school is called in Cuba, did reach the 12th grade while attending school in Cuba. In the Nicaraguan household, of the two adult members, both attended school in Nicaragua though the male only attended school through the seventh grade while the female attended college though she did not earn an undergraduate degree. Of the two adult members of the 
Salvadorian household, the male earned an undergraduate degree in El Salvador while his wife was graduated from high school in the United States. In the Mexican household, neither the oldest adult male or female attended school at any time. Their eldest child, a 24 year old female, went to college locally although she did not graduate. Of their other three adult children, the 23 year old female and the 21 year old male graduated from Southridge Senior High School while their 18 year old sibling was currently enrolled in the eleventh grade at this same school.

Turning to occupations, both members of the Cuban household were retired. In the Nicaraguan household the adult male was a professional musician. Specifically, he played guitar with the house band of a popular Nicaraguan restaurant in Miami. The adult female member of this household worked as a radiologist. In the Salvadorian household, the male household head ran his own yard maintenance business while his wife was involved in sales. In the Mexican household, the two members that worked, (these being the oldest adult male and his oldest son) were involved in agriculture at a nursery.

Household income among the four ranged from between $\$ 5,000$ to $\$ 10,000$ a year to between $\$ 25,001$ to $\$ 30,000$ a year. of the four households the Cuban one averaged between $\$ 5,000$ and $\$ 10,000$ a year and experienced neither an increase nor decrease because of Andrew. The Mexican household, likewise 
averaged between $\$ 5,000$ and $\$ 10,000$ a year before Andrew and did experience a decrease (less than $\$ 5,000$ ) in household income because of Andrew. Additionally, the oldest adult male's place of employment was relocated due to Andrew. A yearly income of between $\$ 15,001$ and $\$ 20,000$ was reported by the Salvadorian household with Andrew decreasing income by $\$ 5,000$ to $\$ 10,000$ from the previous year. Of the four households, the Nicaraguan one reported the highest income which averaged between $\$ 25,001$ and $\$ 30,000$ a year with Andrew having no effect on it.

Turning to the physical description of the houses occupied by these households, the situation can be described as follows. The structure occupied by the Salvadorian household was the newest of the four household residences. From its modern Spanish architectural style it appeared to have been built in the late 1980s. It was a rather spacious home sitting on a lot that was perhaps 60 feet in width by 80 feet in length. This house had two floors and was painted on the exterior in a light pastel pink that came into fashion when Miami Vice was one of the most popular shows on prime time television. Although I did not get to see the entire interior of the house, what I did see of it contained nondescript furniture of contemporary style.

Perhaps a few years older than the above structure was the one occupied by the Nicaraguan household. Although it did 
not have such an obvious architectural style as that occupied by the Salvadorian household, it did have a modern appearance that is very common in this part of South Florida. This was also a rather spacious home located on a piece of property that was probably $60 \times 60$. It had only one floor and was painted on the exterior in a light beige color that, at the time of the second interview, showed every last speck of dirt. Seeing very little of the interior again, what I did see contained a style of furniture somewhat reminiscent of French provincial. ${ }^{12}$

Without question, the houses occupied by both the Cuban and Mexican households were the oldest of the four households interviewed. Both were simple rectangular houses in the distinctive Miami middle-class architectural style commonly found anywhere in Dade County. They both must date from about the same period which I estimated to be the mid to late 1960s. These were both slightly smaller houses than the two described previously and were located on lots that were roughly 50x50. Both houses had recently had their exterior painted in an offwhite color which was already beginning to show the dirt accumulating on the walls. Of these two houses, I only saw very little of the interior of the one occupied by the Cuban household. Similar to the Nicaraguan household, this one contained a French provincial style of furniture.

South Miami Heights, may well represent a different 
picture than other areas in Miami when it comes to the description presented above. For example, the role of the Cuban "enclave" in the area appears to be minimal in comparison to other areas in Miami, such as Hialeah and Westchester. In fact, due to South Miami Heights' ethnically and racially diverse population, the cuban "enclave" may play no discernible role in this neighborhood. However, these differences cannot be the direct focus of this case study. Future comparative work may well pull together other case studies and survey data to draw a more complete picture of the area in question. The focus of this particular project is to provide a case study of the four Hispanic households that participated in this study.

The four subjects interviewed for this research (i.e., South Miami Heights Household Recovery Study) were chosen from the 209 households interviewed in the initial South Miami Heights Survey project carried out by the Florida International University Disaster Research Team. The questionnaire for the South Miami Heights Household Recovery Study was 14 pages in length and began with a series of two questions designed to establish that the present household was the same one which had been interviewed for the first project. Following these questions, came eight which sought to establish residence patterns since the households had immigrated from their individual countries. In this section 
it was also asked when the households had arrived in the United States. The majority of these were open-ended questions which left room for further probing into answers. Four questions dealing with household satisfaction as regarded living in South Miami Heights came next. All of these were open-ended.

The next 16 questions covered debris cleanup after the storm. These dealt with a range of issues such as whether family members not part of the household had helped in the cleanup to whether help had been expected from particular family members. The majority of these questions were openended. 14 questions dealing with relocation followed next. In this section both relocation to the household(s) of family members and other places was covered with open-ended questions. The final section contained 13 questions which inquired more deeply into the type of aid family members not part of the household had provided if, indeed, any assistance had come from this quarter.

\section{Data Collection Techniques}

The households chosen for the Household Recovery Study were selected from among the 209 interviewed for the South Miami Heights Survey by the Florida International University Disaster Research Team. These particular subjects were selected because on the questionnaire from the initial survey 
they had answered that they had done the rebuilding of their home themselves and had not hired a contractor to do it. Further examination of the South Miami Heights Survey questionnaire, showed, that it was highly likely if not certain, that non-residential kin and perhaps non-governmental agencies had helped them in this effort. Since the goal of this thesis was to explore the types of external aid received by households, these households were a natural selection.

For this study, the households were approached on both weekdays and weekends at hours roughly between eight a.m. and nine p.m. When no one was found to be at home, subsequent attempts were made with no further attempt made after four unsuccessful visits. If at the time of any visit the household was not able to dedicate time for the interview at that moment an appointment was made for a later time or date. In order to attempt to interview a household, the interviewer simply knocked on the door or, if someone was outside at the time, simply walked up to that individual. While sample size for the first project made the recording of interviews too expensive to be attempted, all interviews for this study were recorded.

The Cuban household was originally interviewed on June 6 , 1993 for the first study. For the second study, the interview took place on June 22, 1994. English was the language used for the first interview since an adult son of the household 
was present at the time. The second interview was conducted in Spanish with the female member of the household. Both interviews were roughly an hour in length.

The Nicaraguan household was originally interviewed on July 10, 1993 for the first study. For the second study, the interview took place on June 23, 1994. Both interviews were conducted by the author in Spanish. The length of both interviews was roughly an hour and a half.

The Salvadorian household was interviewed for the first project on June 19, 1993 and subsequently on June 25, 1994 for the second project. The first interview took place in the backyard as witnessed by the author. The second interview took place in the living room and was conducted by the author. Both interviews were conducted in Spanish. The length of both interviews was roughly an hour in length. The Mexican household was interviewed for the first project on June 12, 1993 and on June 25, 1994 for the second project. Both interviews took place on the porch and the author conducted the second one. Spanish was the language used for both interviews and both were roughly an hour in length.

Beyond the two primary interview sessions with each of the four household, the author also contacted each household on numerous other occasions following the second primary interview. The reason for these further contacts, was to expand on and clarify previously obtained information. 


\section{ANALYSIS AND RESULTS}

The type of aid offered to victims of a natural disaster takes many forms. One of the most frequent types offered by the non-residential relatives of disaster victims is temporary shelter (Bolin and Trainer 1978; Drabek and Boggs 1968; Drabek and Key 1984). Not surprisingly, food and clothing follow temporary shelter in frequency, though, of course, these three are quite probably offered together more often than not (Erickson et al., ). Monetary loans, on the other hand, are rarely provided by kin but by other sources, such as the federal government (Erickson et al., 1976:209; Rossi et al., 1983). Keeping these types of aid in mind, the aid received by the four households that participated in this study did not venture very far from the norm.

\section{Types of Aid Received}

Looking at non-residential kin aid first, of the four households interviewed for this project the only one that did not receive any non-residential kin aid in recovering from the hurricane was the Mexican one. The reason for this, according to the oldest adult male of the household, was that "they have no other family members in the area." Looking at the other three households individually, the first to receive assistance 
from non-residential kin was the Cuban household, which began receiving aid exactly three days after the storm. The Nicaraguan and Salvadorian households likewise received nonresidential kin aid beginning a few days after Andrew, though it was more than three days for each.

The aid received by the cuban household lasted for a period of roughly five months. Throughout this time two of their daughters, one son, and one grandson provided aid towards household recovery. The type of aid provided by these individuals ranged from simply clearing debris and providing food to major reconstruction of the house on the part of the son. While this household has two sons, one of them lived in Houston (Texas) and was therefore unable to provide more than moral support. Their other son however, who lived in Tampa (Florida), took a period of five months off from work in order to help his parents rebuild their house. During this period of time the parents did provide a salary for the son though they claimed that they did not recall how much it was. The household stated that they did expect assistance to come from their children, at least those residing in Miami, towards their recovery following the storm.

Looking at the aid provided by the son more closely, it took him about five months to rebuild a large percentage of the structure, including the roof. Perhaps surprisingly, he did not appear to tap into the Cuban enclave in order to gain 
assistance in the rebuilding process. In fact, the two individuals that he hired to install the windows and to help repair the roof, he met in the area while they were working on other houses and not through family members or Cuban friends for example.

The supplies for the rebuilding process were bought at large national building supply stores and not local Cubanowned businesses. While this household temporarily resided somewhere else following the storm it was not with family members. The reason given for this in the interview, was because the household wanted to be nearby while their house was being rebuilt so that they could provide assistance if needed. Simply stated, this Cuban household did not appear to have turned to the Cuban enclave in virtually any substantive way when it came to recovering from the hurricane.

The Nicaraguan household did receive non-residential kin aid for a brief period; nevertheless, the majority of aid came from an associate of the adult male. The non-residential kin who provided aid were the husband of the adult female's sister and the brother of the adult male. The male household head's brother-in-law lent money, helped clear debris, and assisted in repairing the air conditioner since he owns his own air conditioner contracting company. The male household head's brother brought food and water for the household.

The majority of aid received by the Nicaraguan household, 
however, came from a Nicaraguan friend of the adult male who helped to rebuild the house. These two individuals had met while working for the same general contractor years earlier. As might be expected, this household did not appear to tap into the cuban enclave, although ethnic solidarity at the national origin level (i.e., Nicaraguan) is significant. Like the Cuban household, this one purchased rebuilding supplies at a national chain. Surprisingly, according to their answers when interviewed, this household had not expected any help from non-residential kin in recovering after the hurricane although they could not say specifically why. Finally, in relocating after the hurricane for a period of 20 days, this household stayed with both of the two non-residential kin mentioned above.

The Salvadorian household received help towards recovery from four non-residential kin. The type of aid provided by these individuals consisted of clearing debris, cleaning up the house, and rebuilding. Furthermore, unlike the other households, this one did mention that non-residential kin "provided psychological and emotional support to get through the hard times after the storm." While help was received from non-residential kin, the adult male in this household stated that he did not expect any because the situation after the storm "was really bad." The rebuilding of this house took over six months and the required supplies were likewise 
obtained at national chain stores. Lastly, this household did not relocate after the storm even though rebuilding took over six months.

The Mexican household, as mentioned above, did not receive any non-residential kin assistance towards recovery, which they attributed to the fact that they did not have any family members living in the area. The work on this house took almost an entire year, much longer than any of the other three households, since it was completely done by the residents. Specifically, the father, when he was not at work, and his two sons rebuilt the structure themselves. Like the other households, building materials were purchased at national building supply stores.

Interestingly, the three households with non-residential kin in the area, (the Cuban, Nicaraguan, and Salvadorian households), stated that prior to the storm none of these kin provided any type of assistance around the house. In other words, not a single non-residential kin member assisted these households in doing any work around the house before the hurricane. However, both the Cuban and Salvadorian households stated that prior to Andrew they did assist non-residential kin with housework, such as cleaning and yardwork, and other things.

Another type of aid which these households received came from the American Red Cross. While all but the Cuban 
household applied for aid from FEMA, this agency offered no assistance since all of the households had homeowner's insurance and, therefore, did not qualify for aid from FEMA. The type of aid offered by the Red cross consisted of credit vouchers so that food, clothes, and shoes could be purchased. Outside of the Red Cross, none of these households received aid from any other government or non-government agencies except for the insurance settlements they received from their insurance companies.

\section{Household Recovery}

By the time the four participating households were interviewed for this study, they all appeared to have substantially recovered. In fact, the respondents stated that they indeed had fully recovered. Specifically, the structures in which they resided had been completely rebuilt and most if not all household possessions had been replaced. Naturally, there was still some minor work to be done on each structure although nothing that required immediate attention. For example, in the Salvadorian household there was still some painting that had to be done. Still, each household stated that the majority of work had been accomplished and that what was left to be done could wait a while.

All four households were very satisfied with how the work on their homes had turned out. Each household specifically 
mentioned the detail work which, if it had been done by a hired contractor, would not have turned out as nicely as it did. The three households which received non-residential kin aid in rebuilding mentioned that they were very grateful for this assistance. Likewise, all four were grateful for the aid which the Red Cross had provided though, the Mexican household felt that the assistance could have been offered sooner than it was.

Still, to an outside observer recovery may not be as complete as was reported by one of the four households. Of the four households, the one that had clearly not reached the level it had prior to the storm was the Mexican one. Specifically, several household possessions, such as electrical appliances, which it had owned before Andrew had not survived the storm and had not been replaced almost two years after Andrew. Conversely, the Cuban household was the only one which had replaced the most pre-Andrew possessions with new ones. While this household had lost most of what it owned prior to Andrew, the other three households had lost just as much. Whether the purchase of new household possessions by the Cuban household can be attributed to the Cuban enclave, however, seems highly unlikely.

\section{The Role of Urban Kinship and the Cuban Enclave}

In looking at the impact that an urban locale had on the 
assistance provided to these four households by nonresidential kin, it is hard to tell whether there was any effect at all. As Hill and Hansen (1962:200-201), Quarantelli (1960), and Wallace (1956a), among others, argue, the extended kin network plays an important role towards the recovery of urban households following a natural disaster. Yet, would the aid provided to these four households from this quarter have been any different if they had lived in a rural area? This is something that the present research cannot answer since it is beyond the focus of this study.

As regards the Cuban enclave, it appears that the Cuban household that took part in this study did not turn towards the enclave in any noticeable way. In fact, it seems that it did not look for help from this quarter at all. The reason for this may be that the two household members are retired and may have lost touch with the relations they had while still employed. Additionally, the son who did the rebuilding does not live in Miami, but in Tampa, and thus may not have had an extensive network in the area. Whatever the reason, the cuban enclave appears to have played no part in the recovery of this particular Cuban household. 


\section{CONCLUSION}

\section{Research Questions and Summary}

This thesis explored the recovery efforts of four Hispanic households, including types of aid received, following Hurricane Andrew. The four households that participated in this study were resident in South Miami Heights, a suburb of the city of Miami in South Florida, at the time of Hurricane Andrew's impact on the area in the early morning hours of August 24, 1992. The national origin of the four households participating in this study were: Cuban, Mexican, Nicaraguan, and Salvadorian.

Hispanic household recovery was the focus of this thesis because of the important role, both socially and economically, that Hispanic groups, especially the Cuban community via the Cuban enclave (Forment 1989; Pérez 1992; Portes 1980; PedrazaBailey 1985), play in Miami. Like most American cities, Miami has a population made up of many different ethnic and racial groups. However, unlike the majority of these cities, in Miami, what is by some definitions a minority group, Hispanics, outnumbers the majority, or Anglos (Grenier and Stepick 1992:5). Furthermore, the Cuban enclave in Miami provides Cubans in the area with numerous opportunities, such as being able to conduct business in Spanish, not available to them in other parts of the United States (Pérez 1992). 
Naturally, the ability to conduct business in Spanish is also available to the other Hispanic groups present in Miami.

Because of the important role that Hispanics occupy in the area, this thesis could not explore household recovery without likewise studying the effects that the Cuban enclave and an urban environment had on this recovery. Several researchers, Becerra (1983, 1988); Graves and Graves (1974:133, 1980); Keefe (1979, 1980); and Mirande (1985), for example, have noted the closeness of non-residential kin relations among Hispanic groups. This closeness has been noted both in the countries of origin and in the countries where Hispanic immigrants have settled. Thus, Williams (1991:242), for example, writes that over 30\% of MexicanAmericans "provided human care and transportation for family members on a weekly or monthly basis." Similarly, SánchezAyéndez (1988:177) reports that among Puerto Ricans extended kin relations are close and interaction occurs regularly.

With regards to the Cuban enclave, the only cuban household to take part in this study does not appear to have turned to the enclave in order to achieve recovery. While the enclave may have had an indirect effect on the recovery of this household, no direct effect was found. Therefore, while the enclave may be of benefit to Cubans or other Hispanics in the area, in this one instance no benefit appears to have been derived by the members of this household when, one would 
assume, they most needed it.

In the process of recovering from the hurricane the only household, of the four that took part in this study, that did not receive any non-residential kin aid was the Mexican one. The stated reason for this is that it had no kin living in the area. In fact, according to the oldest adult male, their nearest kin was his brother who lived in Los Angeles (California). The Cuban household received non-residential kin aid from members that lived in the Miami area as well as from one that lived in Tampa (Florida). While this household stated that prior to the hurricane it helped non-residential kin with work around the house, for example, it also reported that it did not receive such help in return.

The Nicaraguan household also reported that it received non-residential kin aid in its recovery efforts. Likewise, the Salvadorian household reported that it had received nonresidential kin aid towards recovery. As in the case of the Cuban household, both of these stated that prior to the disaster they did not receive extended-kin aid around the house. Additionally, only the Salvadorian household commented that it helped non-residential kin with work around the house prior to the disaster. While, overall, an urban environment does not appear to have weakened non-residential kin relations among the three households with non-residential kin in the area, it is not possible to tell from this sample whether 
extended-kin relations among Hispanics are as important as the literature suggests. Conversely, the sample does not disprove this theoretical viewpoint either. While prior to Andrew, what one would term close relations, did not appear to have existed between these households and non-residential kin, after the disaster they appeared to have become closer. In this light, the argument presented by Hill and Hansen (1962), among others, which reported that even when non-residential kin ties were not close prior to a disaster, after a disaster, substantial aid still arose from this quarter, appears to aptly describe the situation among the three households with non-residential kin in the area that took part in this study. Turning to the types of aid that are offered by kin to family members that are victims of a disaster, several researchers (Bolin and Trainer 1978; Drabek and Boggs 1968; Drabek and Key 1984; Erickson et al., 1976) report that temporary housing appears to be the predominant one. After temporary shelter, the most frequent aid offered to kin affected by a disaster is food and clothing (Erickson et al., 1976:209). Of course, it is very probable that with temporary shelter food and clothing, obvious necessities, are also offered. Beyond these types of aid come numerous others such as transportation and various forms of personal assistance. Perhaps surprisingly, economic aid (i.e., monetary loans or gifts) rarely comes from kin but from other sources, such as 
the government and disaster relief organizations (i.e., American Red Cross, etc.) (Erickson et al., 1976:209; Rossi et al., 1983).

Regardless of the type of aid that may come from nonresidential kin, there is no question that the aid provided by these individuals is very important. Quarantelli (1960), for example, wrote that the extended-family was the first source urban inhabitants turned to for aid following a disaster. Similarly, Drabek et al., (1975:491) reports that kin ties are critical towards achieving recovery following a disaster. Finally, Erickson et al., (1976:205) found that 54\% of the victims of a tornado that struck Topeka (Kansas) in 1966 received kin aid.

of the three households with non-residential kin in the area (the Cuban, Nicaraguan, and Salvadorian households), all three reported receiving some form of aid from non-residential kin. While the majority of the aid received consisted of assistance in clearing debris, other types of aid was also reported. As the literature suggests, food is one of the primary forms of aid offered by non-residential kin as the Cuban and Nicaraguan households stated that they had received food from these individuals. Though only the Nicaraguan household resided temporarily with kin, the literature is not disproved or substantiated on this point. The reason for this, is that the cuban household, while offered temporary shelter 
by non-residential kin, opted not to stay with these individuals in order to be near their house while it was being rebuilt. As for the salvadorian household, it was not possible for them to stay with non-residential kin since all of these had also suffered storm damage. All three of the households with non-residential kin in the area received assistance in rebuilding their houses from these individuals. This was especially critical for the Cuban household, one of whose sons literally rebuilt the entire structure himself. Contrary to the literature, although it does not disprove the hypothesis, the Nicaraguan household reported that it received financial assistance, specifically a loan, from nonresidential kin. Regardless of the type of aid received, there can be no doubt that this aid was critical for the recovery of the three households which received it. This point is best exemplified by the Mexican household which took the longest in rebuilding its house, almost a year, perhaps because it did not have any non-residential kin in the area to help.

Other aid which these households received came from the American Red Cross. All four of the households were given vouchers which permitted them to purchase food, clothing, and shoes. While all four households were satisfied with this aid, the Mexican household commented that it should have been offered much sooner than it was. All four households also 
received insurance settlements from the companies which insured their dwellings. No other source or type of aid outside of those mentioned above was received by any of the households.

South Miami Heights, the area where these four Hispanic households were resident, was an unincorporated working class suburb located about 35 miles south of Miami's center. This neighborhood was like many other neighborhoods in South Florida in that it was dominated by modest single family homes with a few commercial shopping zones scattered throughout. Also found in South Miami Heights were several condominium developments and a few low-rent apartment complexes. The population of South Miami Heights was ethnically and racially diverse, although those with a Hispanic background were most numerous. The population was also predominantly working class and contained many individuals who were self-employed. The educational level of the inhabitants 18 years of age or older varied with only about 23\% having continued beyond high school. Median household income in 1990 was $\$ 28,870$ with median family income slightly higher at $\$ 31,213$. Prior to Hurricane Andrew, there were 594 businesses located in South Miami Heights with over $\$ 1,300,000$ reported in sales for 1992 . Recovery, at the individual, 'family/household, and community/societal levels following a natural disaster has been explored by numerous researchers (Bates and Peacock 1989; 
Bates, Killian, and Peacock 1984; Bolin 1976; Bolin and Bolton 1983; Bolin and Trainer 1978; Hill and Hansen 1962; Wallace 1956a). A common theme in this research is the need of those who have been through a disaster to feel that they have returned to the "way things were" before the disaster in order to feel that they have recovered (i.e., the definition of recovery used for this thesis). The concept of recovery however, is not clear cut as Bates, Killian, and Peacock (1984:443) argue that perhaps returning to the "way things were" should be called restoration and not recovery. Recovery, they go on to argue, should perhaps be limited to a level of attainment that would have been achieved by a household, for example, if the disaster had not occurred and which is eventually reached by the household in the postdisaster period. In a more recent paper, Bates and Peacock (1989:353) argue that perhaps "... the term recovery is misleading and probably ought to be abandoned as a term used to refer to the final stage of the disaster process." The reason for this is that all members of the population recovering from a disaster may not successfully adapt to the new environment following a disaster and may therefore, be more vulnerable in the face of another such event.

Despite the fact that numerous researchers have studied recovery after a natural disaster, very few have looked at the different paths that may be taken to achieve recovery. Bolin 
and Trainer (1978:236-237) for example, delineated three types of family recovery: (1) autonomous mode, where very little aid not originating from within the household is used;

kinship mode, where extensive use is made of non-residential kin aid; and (3) institutional mode, where a high level of government assistance is used. Bates and Peacock (1989:358359) identify two types of recovery. These are: indigenous or independent recovery which is further divided into (a) individualistic self-help mode, (b) collective or cooperative mode, and (c) bureaucratized paternalistic mode; and (2) exogenous or dependent recovery which is further divided into (a) independent beneficiary mode, collaborative partnership, and (c) bureaucratized external paternalism. In the case of indigenous or independent recovery, aid "originates from within the boundaries of the victims' social unit itself." Conversely, aid originates from beyond this unit when it is exogenous or dependent recovery. In spite of these different modes of recovery, all researchers agree that recovery is usually achieved via a combination of modes and not through any single one.

In looking at the four households that took part in this study, it appears that all four have successfully adapted to their new environment and feel as if they have achieved recovery. This appears to be the case in spite of the fact that all four households suffered heavily because of Hurricane 
Andrew. Therefore, their reaction in the face of another disaster is a moot point. However, it must be remembered that of the four households, it is the Mexican one which has not reacquired all that it had prior to the disaster. Specifically, it has not replaced all the household possessions which it lost because of Andrew. A possible reason for this is that it does not have any non-residential kin in the area and could therefore, not turn to such people for help as could the other three households in this study. Still, this household reported that it felt it had recovered from the disaster since its house had been completely repaired and because it had been fortunate as compared to other individuals who had suffered much more due to Andrew.

As for the paths that these households took towards recovery, it consisted of aid from non-residential kin, except for the Mexican household, and two non-governmental organizations (i.e., American Red Cross and insurance companies). The aid received from non-residential kin ranged from debris clearance to major reconstruction. All four households received vouchers from the Red Cross and insurance settlements from their insurers. An interesting point however, is that of the four households the Cuban one solely applied for and received aid from the American Red Cross. The other three households, on the other hand, applied for aid from the Federal Emergency Management Agency (FEMA) even 
though they did not receive any. Still, why did the Cuban household not apply for aid from FEMA, could the presence of the Cuban enclave have had anything to do with it? While this question is not answered by this thesis, it does leave an opening for future research on this topic.

\section{Implications of the study and Recommendations}

The implications of this study for the areas of research on which it focused and recommendations for future research, must be understood in the context of the sample size used in the research. In other words, only four Hispanic working class households were focused on in this thesis and, as such, the implications leave an opening for a larger and more indepth project in these areas. Still, there are some important implications. Primary among these, is the role of the Cuban enclave in Miami. While there is little doubt of the importance of the enclave to Cubans in the area, the fact that the Cuban household in this study did not appear to turn to it for aid at a very critical moment, obviously directs future research to focus on the role of the enclave in the recovery of Cuban households in the Miami area. Specifically, did Cuban households in general turn to the enclave, whether directly or indirectly, for recovery aid? Furthermore, if they did, in what way and for what purpose? If however, they did not turn to it, why was this the case? 
Another aspect of the enclave that needs to be studied in the recovery of Cuban households deals with the characteristics of these households. If indeed, it is found that cuban households turned to the enclave, the socioeconomic level of these households needs to be explored. In other words, did higher socio-economic households turn to the enclave or was it lower socio-economic ones? Conversely, did the socio-economic level of the households matter and, was it in fact, households that had resided in the United states a longer period of time, as opposed to those that arrived in the early 1980 s and more recently, that turned to the enclave?

The role of the enclave for non-Cuban Hispanics must also be explored more closely. While in this study the three nonCuban Hispanic households did not turn to the Cuban enclave for recovery aid, a larger sample, studied in more depth, may find other results. Like with Cuban households, the socioeconomic level and length of residence of the households, if, indeed, any are found that turned to the enclave, should be explored.

The effect of an urban environment on the non-residential kin ties of Hispanic households should also be studied in more detail and on a much larger sample. While in this thesis, the major results reported in the literature were either proved or neither proved nor disproved, a larger study may find different results. It could be, for example, that the non- 
residential kin ties of Hispanic households in the area were much closer in their countries of origin as opposed to how intimate they are in the urban environment of South Miami Heights. In this vein, it is necessary for future research to explore the non-residential kin ties in the homelands of the Hispanic households that are part of the study. This should include both relations prior to a disaster and after a disaster if possible. Still, in this study the nonresidential kin relations for the Cuban, Nicaraguan, and Salvadorian households, while not appearing to have been overly close prior to Andrew, proved invaluable towards recovery following the disaster.

Furthermore, any future research on the areas on which this thesis focused, should look at the post-disaster recovery of Hispanic households more closely as it pertains to nonresidential kin assistance. The study should focus on the socio-economic level of the households participating in the study. For example, are lower socio-economic Hispanic households more likely to receive and offer non-residential kin aid than are higher socio-economic ones? Furthermore, does length of residence in the United States play an important role, if any role at all, in such aid? While the implications of this study are that the aid offered by nonresidential kin, to the three households with non-residential kin in the area, was very critical, future research might find 
different results. For example, it may be that the aid provided by disaster relief organizations, such as the Red Cross and FEMA, is much more important.

Finally, future research might well focus on the psychological and emotional aid offered by non-residential kin to relatives who are victims of a disaster. Perhaps this form of aid is as critical as any other type of assistance offered following a disaster. 


\section{Notes}

1. Because of the length of time since a hurricane had directly impacted South Florida, it was hypothesized that long-term residents would be lax in initiating disaster preparations as compared to newer residents. However, research (Alba and Peacock n.d.) in South Florida following Andrew found the reverse to be true.

2. Wallace states that in contrast to the commonly held sociological view at the time "that extended family ties were relatively unimportant in urban life in America," he found that the "extended family was extremely important in providing shelter for the victims of the tornado" (Wallace 1956:95).

3. Local parlance for non-Hispanic whites.

4. Like most of Miami, South Miami Heights experienced extensive commercial growth in the years preceding Hurricane Andrew.

5. This is not peculiar to South Miami Heights as all canals in South Florida are man made. I learned of this in a marine biology course at Miami-Dade Community College, Kendall Campus.

6. Unless otherwise noted, all statistical data are derived from 1990 U.S. Census of Population and Housing.

7. Miami, like many large cities, is divided into four main sections. These are Northeast, Northwest, Southeast, and Southwest.

8.Homestead Air Force Base and the Coast Guard communication station are the only military installations found in the vicinity of South Miami Heights.

9. It is very likely that the civilian unemployment rate in South Miami Heights jumped dramatically, at least for a period of time, as a result of Hurricane Andrew's destruction of many businesses in the area. Similarly, many individuals who worked in zones not affected or at least severely affected by Andrew were probably unable to work because of damage to their home and mode of transportation.

10. Even though this shopping center was completely destroyed the first time I saw it, it appeared to have been built only a few years prior to the hurricane. I base this assumption on the modern architectural design its shell still 
represented.

11. All data is derived from the South Miami Heights Survey and the South Miami Heights Survey II projects carried out in South Miami Heights in 1993 and 1994.

12. Although I do not know the exact name of this style of furniture, I do know that it is often identified as French provincial. 


\section{References Cited}

Adams, Bert $\mathrm{N}$.

1968 Kinship in an Urban Setting. Chicago:Markham

Publishing Company.

Alba, Manuel R., and Walter Gillis Peacock

n.d. Length of Residence and Disaster Preparedness:

The Case of Hurricane Andrew. Paper Presented at the annual meeting of the Society for Applied Anthropology, San Antonio, Texas.

Alvirez, David, Erank D. Bean, and Dorie Williams

1981 The Mexican American Family. In Ethnic Families in America. 2nd edition. Charles H. Mindel and Robert $W$. Habenstein eds. Pp. 269-292. New York:Elsevier.

Bates, Frederick L., Charles D. Killian, and Walter Gillis Peacock

1984 Recovery, Change, and Development: A Longitudinal Study of the 1976 Guatemalan Earthquake. Ekistics $308: 439-445$.

Bates, Frederick L., and Walter Gillis Peacock

1989 Long Term Recovery. International Journal of Mass Emergencies and Disasters $7(3): 349-365$.

Becerra, Rosina M.

1983 The Mexican American Family: Aging in a Changing

Culture. In Aging in Minority Groups. R.L. McNeeley and John L. Colen eds. Pp. 108-118. Beverly Hills: sage Publications.

1988 The Mexican American Family. In Ethnic Families in America. 3rd edition. Charles H. Mindel, Robert W. Habenstein, and Roosevelt Wright, Jr. eds. Pp. 141-159. New York:Elsevier.

Beer, Linda

1994 Ethnicity and Reaccumulation: An Ecological Analysis. M.A. thesis, Sociology and Anthropology Department, Florida International University.

Bolin, Robert

1976 Family Recovery From Natural Disaster: A Preliminary Model. Mass Emergencies 1:267-277. 
Bolin, Robert, and Patricia Bolton

1983 Recovery in Nicaragua and the U.S.A. International

Journal of Mass Emergencies 1:125-144.

1986 Race, Religion, and Ethnicity in Disaster Recovery.

Program on Environment and Behavior, Monograph 42,

Institute of Behavioral Science, University of

Colorado. Boulder:University of Colorado.

Bolin, Robert, and Lois Stanford

1991 Shelter, Housing and Recovery: A Comparison of U.S.

Disasters. Disasters $15(1): 24-34$.

Bolin, Robert, and Patricia Trainer

1978 Modes of Family Recovery Following Disaster. In

Disasters: Theory and Research. E.L. Quarantelli ed.

Pp. 233-247. London: Sage Publications Ltd.

Calderon, Jose

1992 "Hispanic" and "Latino": The Viability of Categories

For Panthetic Unity. Latin American Perspectives $19(4): 37-44$.

Chavez, Leo R.

1994 The Power of the Imagined Community: The Settlement of Undocumented Mexicans and Central Americans in the United States. American Anthropologist 96:52-73.

Choldin, Harvey M.

1973 Kinship Networks in the Migration Process.

International Migration Review 7(2):163-175.

Cobas, José A.

1987 Ethnic Enclaves and Middleman Minorities: Alternate Strategies of Immigrant Adaptation? Sociological

Perspectives $30(2): 143-161$.

Dash, Nicole

1995 Inequality of Disaster: The Case of Hurricane Andrew

in Florida City. M.A. thesis, Sociology and Anthropology Department, Florida International University.

Dotson, Floyd

1951 Patterns of Voluntary Association Among Urban Working-Class Families. American Sociological Review $16: 687-693$.

Drabek, Thomas E., and Keith S. Boggs

1968 Families in Disaster: Reactions and Relatives. 
Journal of Marriage and the Family $30(3): 1968$.

Drabek, Thomas E., William H. Key, P.E. Ericksen, and J.L. Crowe

1975 The Impact of Disaster on Kin Relationships. Journal of Marriage and the Family 37:481-494.

Drabek, Thomas E., and William H. Key

1984 Conquering Disaster: Family Recovery and Long-Term Consequences. New York: Irvington Publishers Inc.

Erickson, Patricia E., Thomas E. Drabek, W.H. Key, and J.L. Crowe

1976 Families in Disaster: Patterns of Recovery. Mass Emergencies 1:203-216.

Felix-Ortiz, Mario, Michael D. Newcomb, and Hector Myoro 1994 A Multidimensional Measure of Cultural Identity for Latino and Latino Adolescents. Hispanic Journal of Behavioral Sciences 16(2):99-115.

Federal Emergency Management Agency

n.d. Business Profile Report on South Miami Heights.

Fitzpatrick, Joseph P.

1981 The Puerto Rican Family. In Ethnic Families in

America: Patterns and Variations. 2nd edition.

Charles H. Mindel and Robert W. Habenstein eds. Pp. 189214 New York:Elsevier.

Forment, Carlos A.

1989 Political Practice and the Rise of an Ethnic Enclave:

The Cuban American Case, 1959-1979. Theory and

Society: Renewal and Critique in Social Theory 18:4783.

Gaughan, J., and L. Ferman

1987 Toward an Understanding of the Informal Economy. The Annals of the American Academy of Political and Social Sciences 493:15-25.

Graves, Nancy B., and Theodore D. Graves

1974 Adaptive Strategies in Urban Migration. Annual Review

of Anthropology 3:117-151.

Graves, Theodore D., and Nancy B. Graves

1980 Kinship Ties and the Preferred Adaptive Strategies of Urban Migrants. In The Versatility of Kinship. Linda S. Cordell and Stephen Beckerman eds. Pp.195-217 New York: Academic Press. 
Grenier, Guillermo J., and Alex Stepick III

1992 Introduction. In Miami Now! Immigration, Ethnicity, and Social Change. Guillermo J. Grenier and Alex Stepick III eds. Pp. 1-17 Gainesville:University Press of Florida.

Hill, Reuben, and Donald A. Hansen

1962 Families in Disaster. In Man and Society in Disaster. George W. Baker and Dwight W. Chapman eds. Pp. 185-221. New York:Basic Book, Inc.

Keefe, Susan Emley

1979 Urbanization, Acculturation, and Extended Family Ties: Mexican Americans in Cities. American Ethnologist $6: 349-365$.

1980 Personal Communities in the City: Support Networks Among Mexican-Americans and Anglo-Americans. Urban Anthropology 9(1):51-74.

Mirande, A.

1985 The Chicano Experience: An Alternative Perspective. South Bend, IN:University of Notre Dame Press.

Model, Suzanne

1992 The Ethnic Economy: Cubans and Chinese Reconsidered. The Sociological Quarterly 33(1):63-82.

Moore, Joan $\mathrm{W}$.

1971 Mexican Americans and Cities: A Study in Migration and the Use of Formal Resources. International Migration Review 5:292-308.

Muller, M., et al.,

1985 The Fourth Wave: California's Newest Immigrants. Washington, DC:Urban Institute Press.

Neal, David M., Joseph B. Perry, Jr., Ken Green, and Randolph Hawkins

1988 Patterns of Giving and Receiving Help During Severe Winter Conditions: A Research Note. Disasters 12(4): 366-374.

Peacock, Walter Gillis and Betty Hearn Morrow n.d. Long-Term Household Recovery Following a Major Natural Disaster: A Research Proposal. Sociology and Anthropology Department, Florida International University. 
Pedraza-Bailey, Silvia

1985 Political and Economic Migrants in America: Cubans and Mexicans. Albuquerque:University of New Mexico Press.

Pérez, Lisandro

1986 Immigrant Economic Adjustment and Family

Organization: The Cuban Success Story Reexamined.

International Migration Review 20(1):4-20.

1992 Cuban Miami. In Miami Now. Guillermo J. Grenier and Alex Stepick III eds. Pp. 83-108 Gainesville:University Press of Florida.

Perry, Ronald $\mathrm{W}$. , and Alvin H. Mushkatel

1986 Minority Citizens in Disaster. Athens, GA:University of Georgia Press.

Phillips, Brenda D.

1993 Cultural Diversity in Disasters: Sheltering, Housing, and Long Term Recovery. International Journal of Mass Emergencies and Disasters 11(1):99-110.

Porter, J.R., and R.E. Washington

1993 Minority Identity and Self-Esteem. Annual Review of Sociology 19:139-161.

Portes, Alejandro

1980 Immigrants Earnings: Cuban and Mexican Immigrants in the United States. International Migration Review 14

(3) : 315-341.

1987 The Social Origins of the Cuban Enclave Economy of Miami. Sociological Perspectives 30(4):340-372.

Portes, Alejandro, and Robert L. Bach

1985 Latin Journey, Cuban and Mexican Immigrants in the United States. Berkeley:University of California Press.

Portes, Alejandro, and Robert D. Manning

1986 The Immigrant Enclave: Theory and Empirical Examples.

In Competitive Ethnic Relations. Susan Olzak and Joane Nagel eds. Pp. 47-68. New York:Academic Press.

Portes, Alejandro, and Alex Stepick III

1993 City on the Edge: The Transformation of Miami. Berkeley:University of California Press. 
Quarantelli, Enrico L.

1960 A Note on the Protective Function of the Family in Disasters. Journal of Marriage and Family Living (August) :263-264.

Rodriguez, Roberto

1994 The Term 'Non-Hispanic Whites' Invades the Newsroom. Black Issues In Higher Education $11(11): 27-28$.

Rossi, Peter H., James D. Wright, Eleanor Weber-Burdin, and Joseph Pereira

1983 Victimization By Natural Hazards in the United States, 1970-1980: Survey Estimates. International Journal of Mass Emergencies and Disasters 1(3):467-482.

Sánchez-Ayéndez, Melba

1988 The Puerto Rican American Family. In Ethnic Families in America: Patterns and Variations. 3rd edition. Charles H. Mindel, Robert $W$. Habenstein, and Roosevelt Wright, Jr. eds. Pp. 173-195. New York:Elsevier.

Sanders, Jimy M., and Victor Nee

1987 Limits of Ethnic Solidarity in the Enclave Economy. American Sociological Review 52:745-773.

Shoriss, Earl

1992 Latinos: The Complexity of Identity. Report on the Americas 26(2):19-26.

Szapocznik, Jose, and Roberto Hernandez

1988 The Cuban American Family. In Ethnic Families in

America: Patterns and Variations. 3rd. edition.

Charles H. Mindel, Robert $W$. Habenstein, and Roosevelt Wright, Jr. eds. Pp. 160-172. New York:Elsevier.

U.S. Bureau of the Census

1990 Census of Population and Housing. Washington, DC:

U.S. Census Bureau.

Wallace, Anthony F.C.

1956a Tornado in Worcester: An Exploratory Study of

Individual and Community Behavior in an Extreme

Situation. Disaster Study Number 3. Committee on

Disaster Studies. Washington, DC:National Academy

of Sciences-National Research Council Publication 392.

1956b Revitalization Movements: Some Theoretical

Considerations For Their Comparative Study. American

Anthropologist 58:264-281. 
1956c New Religions Among the Delaware Indians. Southwestern Journal of Anthropology $12(1): 1-21$.

1962 Culture and Personality. New York:Random House.

1972 The Death and Rebirth of the Seneca. New York:Vintage Books.

Williams, Flora L.

1991 Interfamily Economic Exchange: A Function of Culture or Economics? Lifestyles: Family and Economic Issues 12 (3) :235-252. 
Appendix

South Miami Heights Household Recovery study Questionnaire 


\section{South Miami Heights Household Recovery Study}

Completion \#

Dwelling Identification:

Street Address

Block \#

Dwelling Unit \#

Mobile home or travel trailer on lot:

Yes, Mobile Home ..... 1 [ ]

Yes, Travel Trailer.. 2 [ ]

No, ............. 3 [ ]

Interview conducted in: English ..... 1 [ ]

Spanish ....2 2 [ ]

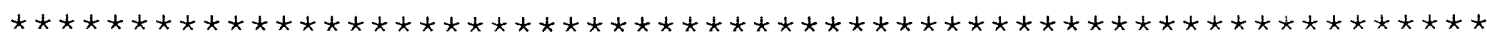

Interview Attempts:

1. Date:

Time:

Result:

2 .

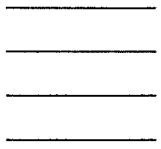

4.
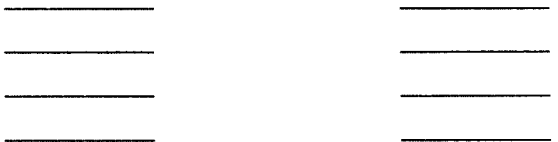

Result Code:

1. No one at home

2. No adult available

3. Appointment made

4. Dwelling appears empty

5. Previous inhabitants moved

6. Interview completed

7. Other:

1. Date:

Time:

Appointment Information

2 .

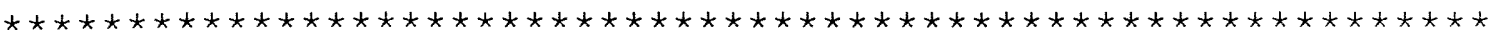

Resident at time of previous interview: Yes ..... 1 [ ] No $\ldots . .26$ 
Florida International University

Department of Sociology and Anthropology

Individual Disaster Research
\#

Date:

Time Started

South Miami Heights Survey on Non-Residential Kin

Assistance Towards Household Recovery

This is a follow-up interview to the one that was conducted a year ago. What I am interested in finding out is what types of assistance towards recovery your household received from family members that do not reside in your household. Remember, just like the last interview, the information you give will be strictly confidential.

First I need to get a little background information:

1. Is your family the one that was interviewed last year by the FIU Disaster Research Team?

$$
\begin{aligned}
& \text { Yes ..... (Skip to question 3)...... } 1 \text { [ ] } \\
& \text { No ...... (Go to question 2)....... } 2 \text { [ ] } \\
& \text { Don't know (Go to question 2) ...... } 3 \text { [ ] }
\end{aligned}
$$

2. How long has your household lived in this residence?

(Date of previous interview:

Years (If a year or longer inquire as to the month and year when they took up residence)

Date residence was taken up: date of previous interview finish Q2 and terminate interview)

Less than a year (Finish Q2 and terminate interview) 0[ ]

2.1 What month did your household move to South Miami Heights?

September ..................... [ ]

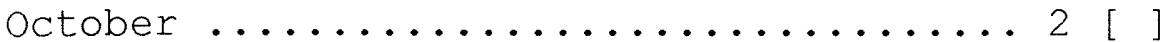

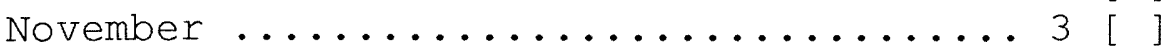

December .................... [ ]

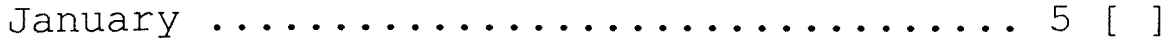

February ..................... [ ]

March .................. [ ]

April .................... 8 [ ]

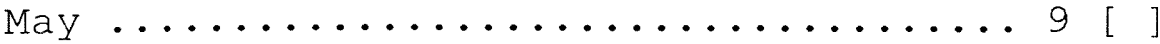

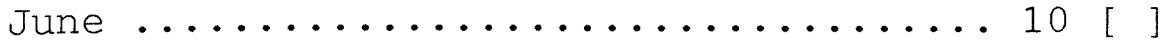

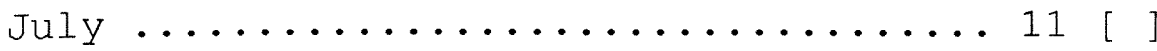

August $\ldots \ldots \ldots \ldots \ldots \ldots \ldots \ldots \ldots \ldots \ldots \ldots \ldots \ldots \ldots \ldots$ 
2.2 Where did your household move from?

2.3 Are you renting or buying this residence? Renting ..................... [ ] Buying/Own .................... [ ] No Response/Refusal ................ 9 [ ]

2.4 And finally, how many people currently live at this residence? Enter \# .................

I want to thank you for talking to me.

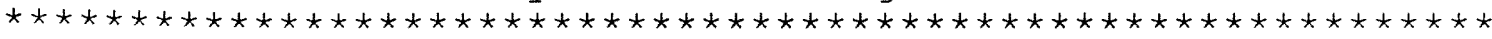

In my first set of questions I want to ask you some information about your household, such as the length of time it has been in the United States.

3. Thinking only of those family members which live in this household, which one(s) came to the United States from another country? (If everyone was born in the U.S. skip to question 6)

Note: IF EVERYONE WAS BORN IN THE U.S. NOTE SUCH AND SKIP TO QUESTION 6 
4. In what year or years did the/these individual(s) arrive in the U.S.?

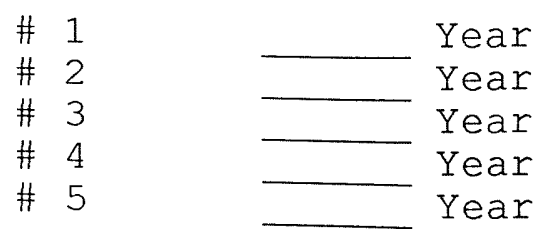

5. Did this/these individuals settle directly in south Florida after arriving in this country?

Yes $\ldots \ldots$ (Skip to question 7) .............. [ ]

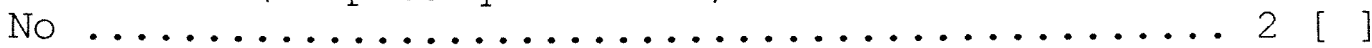

Some did, some did not $\ldots \ldots \ldots \ldots \ldots \ldots \ldots \ldots \ldots .3$ [ ]

5.1 Where did the individual(s) who did not directly settle in South Florida first settle?

$\begin{array}{lll}\# 1 & \text { Location: } \\ \# 2 & \text { Location: } \\ \# 3 & \text { Location: } \\ \# \text { Location: } \\ \text { \# } 5 & \text { Location: }\end{array}$

6. When did this/these individual(s) move to South Florida?

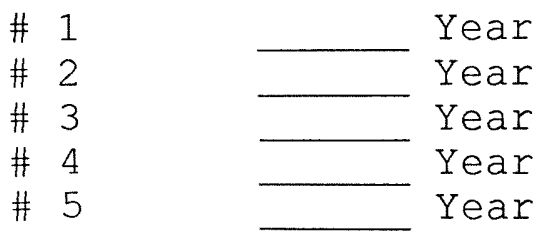

Lived here all their life/lives ..... 1 [ ]

PAY ATTENTION FOR PEOPLE WHO MAY NOT REALIZE THEY LIVE IN AN AREA KNOWN AS SOUTH MIAMI HEIGHTS!

7. Since living in South Florida have this/these individuals always lived in South Miami Heights?

Yes... (Skip to question 8 or $Q 11$ if everyone was born in U.S.).......... 1 [ ]

No $\ldots \ldots \ldots \ldots \ldots \ldots \ldots 2$ [ ]

Note: If everyone was born in the U.S. skip to question 11. 
7.1 Where did this/these individuals live before moving to South Miami Heights?
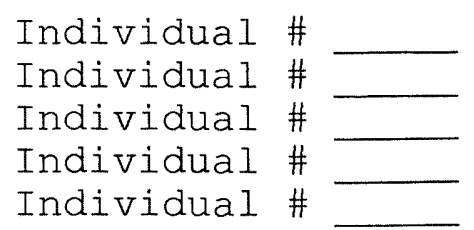

Location Location Location Location Location

8. In what year did the household (EXPLAIN!) which went through Hurricane Andrew begin residing in the United States? Year (Probe as to whether the interviewee regards the household as being established once the first individual(s) arrived in this country or only after being joined by the other family members).

9. Since arriving in the United States has this household always resided in South Florida?

Yes $\ldots$ (Skip to question 10) ... 1 [ [ ]
No ... (Go to question 9.1) ... 2 [ [ ]

9.1 When did this household move to South Florida? (Enter Year and Month)

10. Since arriving in South Florida has this household always resided in South Miami Heights?

Yes ...(Skip to question 11)... 1 [ ]

No .... (Go to question 10.1)... 2 [ ]

10.1 When did this household move to South Miami Heights?

(Enter Year and Month)

11. If you would not mind could you please tell me the reason(s) your household decided to move to South Florida and in particular South Miami Heights?

12. Are you content with your decision to move to this area? Yes $\ldots . .1$ [ ]

No $\ldots . .2$ [ 
Why or why not?

13. What do you like about living in this area (locale, neighborhoods, close to family etc.)?

14. What don't you like about living in this area?

\section{CLEANUP}

15. Did family members not living in your household before or after Hurricane Andrew help you with the cleanup immediately following the hurricane?

$\left.\begin{array}{lllll}\text { Yes } & \ldots & 1 & {[}\end{array}\right]$

16. How about a few days after the hurricane?

Yes $\ldots \ldots 1$ [ ]

No $\ldots . .26$ [ ]

17. How about weeks after the hurricane?

Yes ..... 1 [ ]

No $\ldots . .26\left[\begin{array}{lll} & 2\end{array}\right]$

18. How about months after the hurricane?

Yes $\ldots \ldots \ldots \ldots \ldots \ldots \ldots \ldots \ldots \ldots \ldots \ldots \ldots \ldots \ldots$

No .. (Skip to question 21$) \ldots .2$ [ ]

19. How many family members helped you with the cleanup? (Enter \#) Names: 
20. Tell me what they did to assist you with the cleanup?

21. Prior to the hurricane did family members not living in your household before or after the hurricane come over to assist you with work around the house such as trimming trees or doing repair work around the house?

Yes $\ldots \ldots \ldots \ldots \ldots \ldots \ldots \ldots$ [ [ ]

No.. (Skip to question 22).. 2 [ ]

20.1 How often would you say they did this?

22. Did you help family members not living in your household before or after the hurricane with the cleanup immediately after the hurricane?

Yes $\ldots . .1 \quad 1 \quad\left[\begin{array}{lll}1 & {[}\end{array}\right.$

No $\ldots . .26$ [ ]

Why or why not?

23. How about a few days after the hurricane?

Yes $\ldots . .1$. 1 [ ]

No $\ldots . .26$ [

Why or why not?

24. How about weeks after the hurricane?

Yes $\ldots . .1 \% 1]$

No $\ldots \ldots .2$ [ ]

Why or why not? 
25. How about months after the hurricane?

Yes $\ldots \ldots \ldots \ldots \ldots \ldots \ldots \ldots \ldots$. 1 [ ]

No ..(Skip to question 28 )... 2 [ ]

Why or why not?

26. How many family members not living in your household did you help with the cleanup? (Enter \#)

27. Tell me what you did to assist them with the cleanup?

28. Prior to the hurricane did you help family members not living in your household with work around the house?

Yes $\ldots \ldots \ldots \ldots \ldots \ldots \ldots \ldots \ldots 1$ [ ]

No ...(Skip to question 29) ... 2 [ ]

28.1 How often would you say you did this?

29. Would you say that after the hurricane you expected help in cleaning up from family members not living with you whether the hurricane affected them or not?

30. Would you say that after the hurricane family members not living with you expected you to help them with clean up?

TEMPORARY RELOCATION (Q31 - Q39 ONLY TO BE ASKED OF THOSE HOUSEHOLDS IN WHICH MEMBERS WERE FORCED TO LEAVE THEIR HOME AND STAY WITH RELATIVES) 
31. After the hurricane when you were living with relatives could you tell me which relatives these were?

32. Prior to the hurricane could you tell me what type of a relationship you had with them?

33. How about during your stay?

34. How about now?

35. Besides letting you stay with them how else did these relatives assist you?

36. How long did you stay with them?

37. How close do you live to these relatives now?

37.1 Is this the same distance as before the hurricane? Yes ...(Skip to question 38)... 1 [ ] No $\ldots \ldots \ldots \ldots \ldots \ldots \ldots \ldots \ldots \ldots$

37.1 .1 Is it:

closer ..... 1 [ ]

further ....2 [ ]

38. How often do you see these relatives now? 
39. If you were forced to leave your home again would you stay with these same relatives?

$\left.\begin{array}{lllll}\text { Yes } & \ldots & 1 & {[}\end{array}\right]$

Why or why not?

\section{SKIP TO QUESTION 45}

(Q40 - Q44 ONLY TO BE ASKED OF THOSE WHO WERE FORCED TO LEAVE THEIR HOME BUT DID NOT STAY WITH RELATIVES!)

CHECK HERE IF YES

40. When you were forced to leave your home because of Hurricane Andrew could you tell me why you did not stay with relatives?

41. At any time during the period when you were unable to stay in your home did you attempt to stay with relatives.

Yes $\ldots . .1 \quad 1 \quad[\quad]$

No $\ldots . .26\left[\begin{array}{lll} & 2\end{array}\right.$

42. Were you able to stay with them?

Yes ... (Go back to question 31)... 1 [ ]

No $\ldots \ldots \ldots \ldots \ldots \ldots \ldots \ldots \ldots \ldots \ldots \ldots$

42.1 Why were you unable to stay with them?

43. Prior to the hurricane how would you describe your relationship with these people?

44. How would you describe your relationship with them now? 


\section{FAMILY HELP}

45. How many family members not living with you before or after the hurricane do you have in the U.S.?

(Enter \#)

45.1 ... in South Florida?

(Enter \#)

$45.2 \ldots$ in South Miami Heights?

(Enter \#)

46. Excluding cleanup and temporary shelter how did these family members assist you in recovering from Hurricane Andrew?

(Specify location of individuals, relationship and PROBE into assistance provided)

47. Do you have any family members not living with you before or after the hurricane who are contractors or who work with contractors?

Yes $\ldots \ldots \ldots \ldots \ldots \ldots \ldots \ldots \ldots 1$ [ ]

No .. (Skip to question 49$) \ldots 2$ [ ]

47.1 List relationship and specific occupation.

48. Did these family members help you in rebuilding your home by providing labor, materials or both?

Yes $\ldots \ldots \ldots \ldots \ldots \ldots \ldots \ldots \ldots \ldots \ldots \ldots \ldots$

No ... (Skip to question 48.4 )... 2 [ ]

48.1 If yes: What did they do specifically?

48.1.1 How did the work turn out?

(If not happy with work skip to Q48.3) 
48.2 If satisfied with work: Why?

(Skip to Q48.A)

48.3 If not happy with work: why not?

(Skip to Q48.A)

48.4 If no: Why not?

(Skip to Q49)

48. A How long did the work take?

48.A.1 Do you think the work went faster or slower than if someone else would have done it? Why or why not? PROBE!

49. (IF NO CONTRACTORS, Have they helped ...) Did they help you in any other way such as providing building materials?

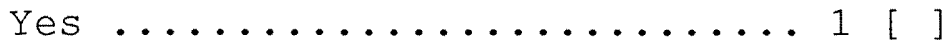

No .. (Skip to question 49.3$) \ldots 2$ [ ]

49.1 If yes: What did they do?

49.1.1 How did it turn out?

(If not satisfied skip to Q49.3)

49.2 If satisfied: Why?

49.3 If no: Why not?

50. Did you work on your home yourself? PROBE! (If yes skip to Q52) 
51. How did you make contact with the contractors that worked on your home? (PROBE)

51.1 If contact was made through family members: Where did these family members know these contractors from, how long have they known them, and what is their relationship to the interviewee?

52. Do you have any family members not living with you before or after the hurricane who were in a position to help you recover because of business connections?

Yes $\ldots \ldots \ldots \ldots \ldots \ldots \ldots \ldots \ldots \ldots \ldots \ldots$ [ ]

No ... (Skip to question 53) .... 2 [ ]

52.1 If yes: What type of business?

52.1.2 What is your relation to these individuals?

53. Did these family members help you in your recovery?

Yes ................. 1 [ ]

No ..(Skip to question 53.2$) \ldots 2$ [ ]

53.1 If yes: What did they do?

53.2 If no: Why not? 
54. Did family members not living with you before or after the hurricane bring you supplies after the hurricane?

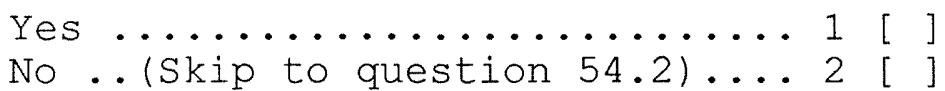

54.1 If yes: What did they bring?

54.2 If no: Why not?

55. Did you receive any help from family members in resolving your insurance matters? PROBE! as to whether they have family members in the insurance business, family members who know agents, etc.

NOTE: Q56 ONLY TO BE ASKED OF THOSE PEOPLE YOU FEEL ARE REALLY OPEN!!!!!

56. Did family members help you out with county inspectors, permits, etc?

57. Is there anything else having to do with family assistance which I neglected to ask you that you feel is important? 